\title{
Siirt'te Bir Nakşî-Hâlidî Merkezi: Zokayd Tekkesi ve Medresesi
}

\section{Mehmet Saki Çakır*}

Atıf/@: Çakır, Mehmet Saki, Siirt'te Bir Nakşî-Hâlidî Merkezi: Zokayd Tekkesi ve Medresesi, Artuklu Akademi 2019/6 (1), 1-33.

Öz: Zokayd tekkesi, 1880'li yıllardan 1990'l1 y1llara kadarki tarihi süreçte Siirt ve çevresinde aktif olmuş bir Nakşî-Hâlidî tekkesidir. Tekke, Şeyh Abdulkahhâr Zokaydî (ö.1906) tarafından günümüzdeki Kurtalan'a bağlı Kayabağlar kasabasında kurulmuştur. Bu tekkedeki şeyhler, Hâlidîlik öğretilerine göre tasavvufî eğitim verirken; medresede de müderrislik yapmışlardır. Şeyhlerin geride halife bırakmamaları, daha çok müderrislik yönlerinin ön planda olmalarından kaynaklanmaktadır. Medreseye verdikleri ihtimam ise mensup olduklar1 Molla Halil es-Si'irdî ailesinin bölgedeki belirgin özelliğidir. Tekke, irşad faaliyetlerinin yanı sıra sosyal ve siyasal gelişmelere de kayıtsız kalmamıştır. Bu manada Şeyh Abdulkahhâr, Yezîdî Batran köyünün Müslüman olmasına öncülük etmiştir. Oğlu Şeyh Mahmud (ö.1945) ise müridleriyle birlikte I. Dünya savaşına katılmıştır. Cumhuriyet döneminde şeyhlerin sürgün edilmesiyle, tekkedeki faaliyetler zaman zaman aksamakla birlikte tamamen kesilmemiş ve yakın döneme kadar devam etmiştir. Bu çalışmada Osmanlı'nın son dönemlerinden itibaren faaliyet gösteren Zokayd tekkesinin tasavvuf tarihindeki konumu ele alınmıştır.

Anahtar Kelimeler: Zokayd, Hâlidîlik, Nakşibendiyye, Medrese, Siirt.

\section{A Naqshī-Khālidī Sufi Centre in Siirt: The Takka and Madrasa of Zoqayd}

Citation/@: Çakır, Mehmet Saki, A Naqshī-Khālidī Sufi Centre in Siirt: The Takka and Madrasa of Zoqayd, Artuklu Akademi 2019/6 (1),1-33.

\begin{abstract}
Zoqayd is a Naqshī-Khālidī sufi order (takka) which was active in Siirt and in Siirt province from the 1880s until the 1990s. The sufi order was established by Sheikh Abd al-Qahhār Zoqaydī (d.1906) in Kayabaglar town of Kurtalan. The sheikhs in this sufi order not only trained the followers according to the Khālidī sufi principles, but they also taught Islamic sciences in the madrasa. The reason why, the sheikhs did not leave behind a caliph is because the education in madrasa was highly active in comparison to the sufi order. The importance they attach to the madrasa comes from the characteristic of the family
\end{abstract}

* Dr. Öğr. Üyesi, Siirt Üniversitesi İlahiyat Fakültesi Tasavvuf Anabilim Dalı, m.saki@hotmail.com. 
of the Mulla Khalìl al-Siirdì to which they belong. At the same time, the sufi order was also concerned with social problems and political conflicts. For instance, Sheikh Abd al-Qahhār leaded the Yazidīs in the Batran village in the conversion to Islam. His son Sheikh Mahmūd (d.1945) defended the region with his followers (murīds) during World War I. With the exile of the sheikhs in the Republican period of Turkey, the activities in the sufi order have decreased, but not completely extinguished. Until recently, the activities have carried on. In this study, the position of takka of Zoqayd in the history of Sufism has been investigated.

Keywords: Zoqayd, Khālidyyah, Naqshbandiyya, Madrasa, Siirt.

[The Extended Abstract is at the end of the article.]

\section{Giriş}

Tasavvufî eğitimin tatbik edildiği merkezler, bulundukları toplumun değişim ve gelişiminde iz bırakmışlardır. Tekke, dergâh, hânkâh gibi isimlerle anılan bu merkezlerde, toplumun her kesiminden insanları görmek mümkündür. Bu mekânlardaki sohbet ve zikir meclislerinde yetişen zatlar, tecrübe edindikleri tasavvufî hakikatlerle hayatlarına yön verip insan-1 kâmil olmuşlardır. Dolayısıyla bu merkezlerin etkili olduğu bölgedeki insanların dinî, sosyal ve kültürel yapılarını sağlıklı bir biçimde değerlendirmek için, sahip oldukları tasavvufî bakış açısının mutlaka dikkate alınması gerekmektedir.

Siirt'te bulunan Nakşî-Hâlidî Zokayd tekkesi yakın döneme kadar faaliyet gösteren tekkelerden biridir. Zokayd tekkesi, XIX. yüzyılın sonlarında Siirt'in Garzan kazasına bağlı Zokayd köyünde (günümüzde Siirt'in Kurtalan ilçesine bağlı Kayabağlar kasabası) kurulmuştur. Şeyh Abdulkahhâr Zokaydî’nin (ö.1906) kurduğu bu tekke, tarihi süreçte bölgede tasavvufî bir anlayışın yerleşmesinde büyük rol oynamıştır. Öyle ki günümüzde Siirt ve çevresinde tekkenin bıraktığı izler hala gözlemlenebilmektedir.

Literatürde Zokayd tekkesi şeyhlerinin eserlerini konu edinen bazı çalışmalara rastlanmaktadır. ${ }^{1}$ Ancak bu çalışmalar, eserleri inceleyip tekkeyi bir bütün olarak yansıtmaktan uzaktır. Yine Zokayd tekkesi şeyhlerinin hayatını ele alan bazı çalışmalar ise tasavvuf merkezli bir hüviyete sahip

1 Bu çalışmaların bazıları için bkz. Abid Sevgili, “Şeyh Mahmud ez-Zokaydî ve 'ed-Dâ' ve'd-Deva' Adlı Eseri”, (Yayınlanmamış Yüksek Lisans Tezi, Dicle Üniversitesi Sos. Bil. Enst., Diyarbakır 2011); Hamit Sevgili, "Şeyh Mahmûd Zokaydî'nin 'Kitâbu âdâbi'l-hukûki ve hüsni's-suhbe' Adlı Eseri Bağlamında Âdâb-1 Muâşeret ile İlgili Görüşleri”, Siirt Üniversitesi Sosyal Bilimler Enstitüsü Dergisi, 5/10 (2017): 599621; Abdurrahman Adak, "Şeyh Cüneyd-i Zokaydî ve Mahtut Bir Şiir Mecmuası", Şarkiyat İlmi Araştırmalar Dergisi, $1 / 1$ (Nisan 2009): 133-139. 
değildir. ${ }^{2} \mathrm{Bu}$ makalede, Zokayd tekkesinin postnişînleri, medresesindeki müderrisler, burada yetişen sûfîler ve âlimler ele alınmış; onların yürüttüğü faaliyetler kapsamında tekkenin dinî-sosyal ve sosyo-politik etkileri tasavvufî bakış açısıyla incelenmiştir. Böylece bir bütün olarak tekkenin tasavvuf tarihindeki konumu ortaya konulmuştur. Ayrıca bu makalede, daha önceki çalışmalarda bulunmayan bazı kaynak eserler ve arşiv kayıtları da kullanılmiştır.

Tekkenin postnişînlerine geçmeden önce, temsil ettikleri Hâlidîlik ekolüne kısaca değinmekte fayda vardır. Mevlânâ Hâlid-i Bağdâdî́nin (ö.1827) XIX. yüzyıldaki etkin ve yaygın irşadıyla Nakşibendîlik, kendisinden sonra Hâlidiyye koluyla anılmaya başlamış ve değişik coğrafyalarda günümüze kadar devam edegelmiştir. ${ }^{3}$ Yüzlerce halifesi olan Mevlânâ Hâlid'in Anadolu'da etkili halifelerinden biri de Seyyid Taha Hakkârí'dir (ö.1853). Seyyid Taha, Hakkâri'nin Şemdinli ilçesinde bulunan Nehri (Bă̆lar) merkezli irşadıyla, günümüzdeki Irak, İran ve Türkiye coğrafyasında özellikle sınır hattında- birçok halife yetiştirmiştir. En etkili halifelerinden biri, Gayda tekkesinin kurucusu Seyyid Sıbgatullah Arvâsî́dir (ö.1870). Arvâsî̀nin halifesi Şeyh Abdurrahman Tâğî (ö.1886), Bitlis'teki Norşin tekkesinde on dokuz halife yetiştirmiştir. Bu halifelerinden bazısı, kendi bölgelerinde etkin bir biçimde Hâlidîliği temsil etmişlerdir. İşte bunlardan biri de Zokayd tekkesinin kurucusu Şeyh Abdulkahhâr'dır. Buradan hareketle Zokayd tekkesini, Hâlidîlik geleneğini yerel biçimde temsil eden bir merkez olarak konumlandırabiliriz. Dolayısıyla tekkenin öğretileri, Nakşî-Hâlidî tasavvuf anlayışından ibarettir. ${ }^{4}$

\section{Postnişînlerin Mensup Olduğu Molla Halil es-Si'irdî Ailesi}

Zokayd tekkesi postnişînlerini tanıtmadan önce, mensup oldukları Molla Halil es-Si'irdî ailesinden bahsetmek gerekmektedir. Son dönem Osmanlı müelliflerinden olan Molla Halil, 1164/1750 yılında Hizan'a bağlı Gulpik (Süttaşı) köyünde doğmuştur. Soyu, Abdülkadir Geylânî'nin (ö.561/1165-66) muasırı Şeyh Musa ez-Zûlî́ye dayandırılmaktadır. ${ }^{5}$ Bölge-

2 Bkz. Mehmet Macit Sevgili, "Zokayd Medrese ve Tekkesinin Veysel Karenî Yöresindeki Etkileri”, Uluslararası Veysel Karenî ve Mânevî Kültür Mirasımı Sempozyumu, 20-21 Mayıs 2011 Siirt, ed. Mehmet Bilen ve Şevki Efe, Matser Basım Yayım, (Ankara: 2012), 193-213.

3 Hâlidîlik hakkında detaylı bilgi için bkz. Abdulcebbar Kavak, Mevlânâ Hâlid-i Nakşibendî ve Hâlidîlik, (İstanbul: Nizamiye Akademi, 2016).

4 Zokayd tekkesinin Seyyid Taha Hakkarî́ye kadar uzanan silsilesi hakkında daha fazla bilgi için bkz. İbrahim Baz, Şeyh Asım Ohinî ve Birketü'l-kelimât fî menâkıb-ı ba'di's-sâdât İsimli Eseri, (İstanbul: Nizamiye Akademi, 2018).

5 Fudayl Zokaydî, Menâkıbu'l-vâlidi'l-üstad eş-Şeyh Mahmud ez-Zokaydî ve'l-cedd eş-Şeyh Abdulkahhar, (y.y., 1400/1980), 1 (referans verilirken eserdeki mevcut sayfa numaraları esas alınmıştır). Abdulvehhab 
deki birçok farklı medresenin yanı sıra Irak'ta da ilim tahsil eden Molla Halil, icazet aldıktan sonra genç yaşta müderrislik yapmaya başlamıştır. Farklı medreselerden eğitim alması, kuşkusuz ilmî derinliğe haiz olmasına katkıda bulunmuştur. Bir yandan talebe yetiştiren es-Si'irdî, diğer taraftan da farklı alanlarda onlarca eser telif etmiştir. Eserlerinin bir kısmı yeni keşfedilse de verdiği klasik medrese eğitimi yetiştirdiği talebeleriyle devam etmektedir. es-Si'irdî, 1259/1843 yılında Siirt'te vefat etmiş ve burada defnedilmiştir. ${ }^{6}$ Ondan sonra başta oğlu Molla Mustafa olmak üzere, çocukları ve torunları medrese eğitiminin yaygınlaşmasına hizmet etmişlerdir. Nihayetinde bölgedeki medreselerde eğitim gören binlerce talebenin geçmişinde Molla Halil ailesinin izlerini görmekteyiz. Bundan dolayı Şark medreselerinin genelinin ilmî icazeti Molla Halil'de birleşmektedir.

Müderrisliği ön planda olan Molla Halil, Kâdiriyye tarikatı şeyhlerinden Kuzey Irak'taki Musul şehrinde bulunan Şeyh Ahmed Reşidî’ye intisap etmiş ve ondan hilafet almıştır. Ancak bir tarikat şeyhinden ziyade müderris olarak şöhret bulmuştur. Onun bu özelliğine dair muasırı Seyyid Sıbgatullah Arvasî şöyle der: "Molla Halil'in cezbesi Sultan Memduh Tillovî (ö.1847) gibiydi. Ancak o, cezbesini zahiri ilimler ile örttü."7 Molla Halil' in tasavvufa dair bilinen bazı eserleri şunlardır:

1. Minhâcu's-sünneti's-seniyye fî âdâbi sulûki's-sûfiyye/Zâdu's-sâlikin

2. Risâle fî şurûti'l-halve ve âdâbihâ

3. Nebzetu'l-mevâhibi'l-ledunniyye fi'ş-şetahât ve'l-vahdeti'z-zâtiyye

4. [İbn Arabî'nin itikadına dair risale $]^{8}$

Şarânî́nin bildirdiğine göre, Şeyh Musa b. Mâhîn ez-Zûlî, Şeyh Abdülkâdir Geylânî́nin muasırı olup onun övgüsüne mazhar olmuştur. Birçok kerameti olan ez-Zûlî, Mardin'e yerleşmiş ve orada vefat etmiştir (Abdulvehhab Şarânî, et-Tabakâtü'l-kubrâ: Levâkıhu'l-envâri'l-kudsiyye fi menâkibi'l-ulemâ ve's-sûfiyye, thk. Ahmed Abdurrahim es-Sâyih ve Tevfîk Ali Vehbe, (Kahire: Mektebetü's-Sakafetü'd-Diniyye, 2005), I, 248249. Şeyh Musa'nın kabri, Mardin-Diyarbakır arasında bir mevkidedir. Bölge halkı ona saygı gösterip kabrini ziyaret etmektedir.

6 Hayatı hakkında detaylı bilgi için bkz. Abdulkahhar Zokaydî, Tercemetü el-Allâme el-Fehhâme el-Molla Halil, (y.y., trsz.); İsmail Paşa el-Bâbânî el-Bağdâdî, Hediyyetü'l-'ârifinn, (Beyrut: Dâru ihyâi't-turâsi'l-Arabî, 1951), I, 357; Ömer Pakiş, "Molla Halîl es-Siirdî”, Türkiye Diyanet Vakfi İslâm Ansiklopedisi (DİA), (İstanbul, Türkiye Diyanet Vakfı, 2005), XXX, 250.

7 Zokaydî, Menâkıbu'l-vâlidi'l-üstad eş-Şeyh Mahmud ez-Zokaydî ve'l-cedd eş-Şeyh Abdulkahhar, 55-56.

8 Zokaydî, Tercemetü el-Allâme el-Fehhâme el-Molla Halil, 2. Molla Halil'in eserlerinin birçoğu Siirt'te torunları tarafından muhafaza edilmektedir. 


\section{Zokayd Tekkesi Postnişînleri}

\section{A. Şeyh Abdulkahhâr Zokaydî (ö.1906)}

Zokayd tekkesinin kurucusu Şeyh Abdulkahhâr Molla Mahmud'un oğlu, o da Molla Halil es-Si'irdî’nin oğludur. 1260/1844 yılında, babası Siirt Eruh'a bağlı Tanze (Kavaközü) köyündeyken; kendisi Eruh'a bağlı Hergule (Yediyaprak) köyünde doğmuştur. ${ }^{9}$ Medrese eğitimini amcazâdesi Molla Ömer'den alan Şeyh Abdulkahhâr, ondan icazet aldıktan sonra aynı medresede müderrislik yapmıştır. ${ }^{10}$

Molla Abdulkahhâr'in tasavvufa yönelmesi ise Şeyh Hâlid Orekî (ö.1877-78) ile yaşadığı bir olay sonrasında gerçekleşmiştir. Molla Abdulkahhâr; Orekî̀nin, mürşidi Sıbgatullah Arvasî̀ye hizmet ederken bazı aşırı davranışlarda bulunmasını eleştirir. Bu manada Arvasî́nin onun sırtına basıp bineğine binmesini, ilmin saygınlığını düşürücü olarak yorumlar. Bunun üzerine Orekî, bu davranışların muhabbetten kaynaklandığını belirtip kendisinin de bu zevki tatması için duada bulunur. Bundan etkilenen Molla Abdulkahhâr, "Bu andan itibaren amelsiz ilmin, meyvesiz ă̆aç olduğunu çok daha iyi idrak ettim." der ve tasavvufa yönelmeye karar verir. ${ }^{11}$

Zikredilen olaydan sonra gönlünde bir mürşide bağlanma arzusu oluşan Şeyh Abdulkahhâr, önce Siirt'e bağlı Firsaf (Dereyamaç) köyünde bulunan Nakşî-Hâlidî Şeyh Muhammed Hazîn Firsâfî́ye (ö.1892)12 intisap edip ondan bir müddet tasavvufî eğitim alır. Daha sonra ondan ayrılır ve başka bir mürşid arayışına koyulur. Bu esnada Norşin'deki Şeyh Abdurrahman Tâğ̂́yi ziyaret eder ve ondan etkilenir. Ancak intisap etmeden önce bu tekkenin şeriat kurallarına riayetini gözlemler. Bu hususta mutmain olan Şeyh Abdulkahhâr, Şeyh Abdurrahman'a intisap edip tasavvufî eğitimini onun yanında ikmal eder. Şeyh, ona hilafet verdiğinde görevin ağırlı̆̆ından dolayı başta kabul etmez. Daha sonra şeyhinin yönlendirmesiyle Sıbgatullah Arvâsî'nin merkadını ziyaret ederken, vakıa yoluyla ondan irşad etmesi gerektiğine dair işaret aldığını belirtir. ${ }^{13} \mathrm{Bu}$ gelişmeden sonra irşad vazifesini

\footnotetext{
Zokaydî, Menâkıbu'l-vâlidi'l-üstad eş-Şeyh Mahmud ez-Zokaydî ve'l-cedd eş-Şeyh Abdulkahhar, 35.

Sevgili, “Şeyh Mahmud ez-Zokaydî ve ed-Dâ' ve'd-Deva' Adlı Eseri”, 31.

11 Zokaydî, Menâkıbu'l-vâlidi'l-üstad eş-Şeyh Mahmud ez-Zokaydî ve'l-cedd eş-Şeyh Abdulkahhar, 2-3. Âsım Ohinî, Birketü'l-kelimât, (y.y., trsz.), 19; Şefik Korkusuz, Nehrî'den Hazne'ye Meşayih-i Nakşibendî, (İstanbul: Pak Ajans Yayıncılık Ltd. Şti., 2010), 130-131.

12 Şeyh Osman Siracuddin'nin halifelerindendir. Tarikatı daha çok Siirt ve çevresinde yayılmıştır. Detaylı bilgi için bkz. İbrahim Baz, Şeyh Muhammed Hazîn Firsâfî: Hayatı Eserleri ve Görüşleri, (Ankara: İlahiyat Yayınları), 2016.

13 Zokaydî, Menâkıbu'l-vâlidi'l-üstad eş-Şeyh Mahmud ez-Zokaydî ve'l-cedd eş-Şeyh Abdulkahhar, 4-5.
} 
üstlenir. Şifahi olarak aktarılan menkıbelerde Şeyh Abdulkahhâr'ın, bölgede Hz. Veysel Karanî’ye nisbet edilen merkaddan da feyz aldığ 1 anlatılır. ${ }^{14}$

Mürşidine tam bir muhabbet ve teslimiyet ile bağlanan Şeyh Abdulkahhâr, bu halini birçok davranış ve sözlerinde göstermiştir. Bu durum, Seyyid Taha'nın oğlu Şeyh Ubeydullah Nehrî́yle (ö.1883) olan diyalogunda; Nehrî́nin, şeyhine yönelik itirazlarına karşı kendi şeyhini savunmasında belirgin bir biçimde görülmektedir. Onun bu münakaşası Şeyh Abdurrahman'a iletildiğinde "mürşidim Seyyid Sıbgatullah Arvasî̀yi savunduğu için bir beis görmedim." yorumunda bulunmuştur. ${ }^{15}$

Şeyhinin telkiniyle Siirt'e bağlı Halenze (Bağtepe) köyüne yerleşen Şeyh Abdulkahhâr, bulunduğu mıntıkaya yakın olması münasebetiyle nezaketen ilk şeyhi, Şeyh Muhammed Hazîn'den izin alarak irşada başlar. Daha sonra Siirt'in doğusunda bulunan Botan bölgesinde irşadina devam eder. Bu arada Botan bölgesindeki birçok köy ona intisap eder. Botan bölgesinden sonra Kurtalan'ın yakınındaki Gurdilan mıntıkasına geçer. ${ }^{16}$ Mürşidi Şeyh Abdurrahman'ın talimatı üzere en sonunda Garzan'a bağlı Zokayd köyüne yerleşen Şeyh Abdulkahhâr, burada bir tekke ve medrese inşa eder. Bu dönemin başlangıcı, 1880'li yıllara tekabül etmektedir.17

Garzan bölgesinin önemli bir kısmında halkı irşad eden Şeyh Abdulkahhâr'1n, Beşiri ve Kozluk bölgelerinde de müntesipleri olmuştur. ${ }^{18}$ Daha önceki irşad sahalarıyla birlikte genel çerçeveye bakıldığında, irşadının Siirt'in büyük bir kısmında etkili olduğu söylenebilir. Ayrıca dönemin idarecileri ve kanaat önderlerinin de Şeyh Abdulkahhâr'a saygı gösterdiği belirtil-

14 Zokaydî, Menâkıbu'l-vâlidi'l-üstad eş-Şeyh Mahmud ez-Zokaydî ve'l-cedd eş-Şeyh Abdulkahhar, 96; Sevgili, "Zokayd Medrese ve Tekkesinin Veysel Karenî Yöresindeki Etkileri", 201.

15 Şeyh Ubeydullah Nehrî, Sultan Abdülhamid tarafından İstanbul'a çağrıldığında Hakkarî́ den yola koyulur ve yolda Muş Malazgirt'te konaklar. Bunu duyan Şeyh Abdurrahman Tâĝ̀, kendi memleketine geldiğinden onu karşılamaları gerektiğini düşünür. Ancak Nehrî’den mürşidi Seyyid Sıbgatullah Arvasî aleyhine dair bazı konuşmaları işittiğinden aralarında soğukluk vardır. Herhangi nahoş bir durum olmaması için kendisi gitmez ve halifesi Şeyh Fethullah Verkânisî önderliğinde halife ve müridlerinden bir heyet gönderir. Heyettekiler, Şeyh Ubeydullah'ın yanına vardığında, ona saygı ve hürmette kusurda bulunmazlar. Şeyh Ubeydullah ise kendilerine, babası Seyyid Taha'nın Seyyid Sıbgatullah Arvasî́yi tarikattan tard ettiğini söyler. Oradakiler böyle bir bilgiyi işitmediklerini ifade ederler. Bu esnada heyetteki Şeyh Abdulkahhar, öne atılır ve böyle bir şeyin söz konusu olmadığını söyler. Bunun üzerine Şeyh Ubeydullah, "Eğer babam tard etmediyse, babamın tarikatından ben tard ediyorum." gibi bir ifade kullanır. Şeyh Abdulkahhar buna yetkisinin olmadığını şöyle savunur: "Hepinizin ilim icazeti dedem Molla Halil'e ulaştığı halde ben bu icazeti sizden geri alamadığım gibi Şeyh Ubeydullah da babasının verdiği tarikat icazetini geri alma yetkisine sahip değildir (Zokaydî, Menâkıbu'l-vâlidi'l-üstad eş-Şeyh Mahmud ez-Zokaydî ve'l-cedd eş-Şeyh Abdulkahhar, 17-19; Ohinî, Birketü'l-kelimât, 56). Aynı olayı Şeyh Ubeydullah'ın kâtibi Abdurrahim Vefâ̂ de anlatmıştır. Ancak Vefâî Şeyh Ubeydullah'ın gelen kişilere, Abdurrahman Tâğî́nin şeyhliğini kabul etmediğini söyleyip onları huzurundan çıkardığından bahseder. Mirza Abdurrahim Savicbulağî Vefâî, Tuhfetü'l-mürîdîn, Hacı Şefi' Hızırî Özel Aile Arşivi, Uşneviyye, 127-128.

16 Zokaydî, Menâkıbu'l-vâlidi'l-üstad eş-Şeyh Mahmud ez-Zokaydî ve'l-cedd eş-Şeyh Abdulkahhar, 6.

17 Zokaydî, Menâkıbu'l-vâlidi'l-üstad eş-Şeyh Mahmud ez-Zokaydî ve'l-cedd eş-Şeyh Abdulkahhar, 5-6.

18 Zokaydî, Menâkıbu'l-vâlidi'l-üstad eş-Şeyh Mahmud ez-Zokaydî ve'l-cedd eş-Şeyh Abdulkahhar, 6. 
miştir. ${ }^{19}$ Şeyh Abdulkahhâr, heybetiyle meşhur iken, müridleri ise cezbe ehli kişiler olarak tavsif edilmiştir. ${ }^{20}$ Ancak o, yetiştirdiği müridlerinden geride halife bırakmamıştır.

Şeyh Abdulkahhâr, halife yetiştirmese de birçok önemli şahısta derin izler birakmıştır. Bunlardan biri, talebesi Şeyh Abdülhakim Ceznî’dir. Ceznî, Şeyh Abdurrahman Tâğî́nin halifesi olmasına rağmen şeyhi, irşad görevini Şeyh Abdulkahhâr'ın iznine bağlamıştır. ${ }^{21}$ Yine Şeyh Abdulkahhâr'ın zikir ve sohbet meclislerine katılanlar arasında, amcazâdesi ve dönemin Siirt müftüsü Molla Hüseyin Efendi'nin de olduğu kaydedilmiştir. ${ }^{22}$ Şeyh Abdulkahhâr'ın maneviyatından istifade edenlerden biri de Adıyaman Menzil dergâhının kurucusu Seyyid Abdülhakim Bilvanisî́dir (ö.1972). Rivayete göre Seyyid Abdülhakim, daha küçük yaşlardayken Siirt'e bağlı Arınç köyüne gelen Şeyh Abdulkahhâr'ı ziyaret eder. Şeyh, onu kucaklayarak onun hakkında: "Bu çocukta bir ışık görüyorum. Ancak bir kusuru var ki çok halimdir." şeklinde bir ifade de kullanır. ${ }^{23}$ Yine ondan manevi feyz alanlardan biri Said-i Nursî́ dir (ö.1960). Said-i Nursî, bölgedeki medreselerde ilim tahsil ederken yaşadığı bir rahatsızlıktan dolayı Şeyh Abdulkahhâr'ın yanına gider. ${ }^{24}$ Ziyaret esnasında iyileşen Nursî, y1llar sonra şeyhin torunu Şeyh Fudayl'a gönderdiği bir mektupta Şeyh Abdulkahhâr'dan övgüyle bahseder. $^{25}$

Halkı irşad ederken Nakşibendiyye tarikatının önemini vurgulayan Şeyh Abdulkahhâr'a göre bu tarikat, kıymetli ve nadir bulunan "kibrit-i ahmer" gibidir. Bu manada sadece zahiri ilimlerle yetinmeyen Mevlânâ Hâlid örneğinden bahseder. Nitekim Mevlânâ Hâlid, zahiri ilimlerde yetkin bir müderris iken Nakşibendiyye tarikatına intisap etmek için Süleymani-

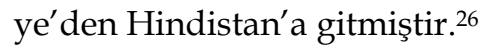

İsşad ve tedris gibi faaliyetlerin yanı sıra hattatlı̆̆ıyla da meşhur olan Şeyh Abdulkahhâr, dedesi Molla Halil'in birçok eserini istinsah etmiştir.

19 O dönemde Garzan bölgesi miri/müdürü Fettah Bey idi. Şeyh Fudayl'in bildirdiğine göre, Fettah Bey, başka şeyhe intisap ettiğinden Şeyh Abdulkahhar'dan izin isteyip müridi olmamışsa da onun çocukları ve torunları Şeyh Abdulkahhar'a intisap etmiştir. Bkz. Zokaydî, Menâkıbu'l-vâlidi'l-üstad eş-Şeyh Mahmud ezZokaydî ve'l-cedd eş-Şeyh Abdulkahhar, 11-12.

20 Zokaydî, Menâkıbu'l-vâlidi'l-üstad eş-Şeyh Mahmud ez-Zokaydî ve'l-cedd eş-Şeyh Abdulkahhar, 14-15.

21 Zokaydî, Menâkıbu'l-vâlidi'l-üstad eş-Şeyh Mahmud ez-Zokaydî ve'l-cedd eş-Şeyh Abdulkahhar, 5.

22 Zokaydî, Menâkıbu'l-vâlidi'l-üstad eş-Şeyh Mahmud ez-Zokaydî ve'l-cedd eş-Şeyh Abdulkahhar, 6.

23 Mehmed Ildırar-Ahmed Çağıl, Seyyid Abdülhakim El-Hüseynî (Gavs-ı Bilvanisî Hayatı), (Ankara: Menzil Kitabevi, 1996), 18.

24 Abdurrahman Nursî, Bediüzzaman'ın Hayatı, yay. Osman Resulan, (İstanbul: Nubihar Yayınları, 1997), 1617; Sevgili, "Zokayd Medrese ve Tekkesinin Veysel Karenî Yöresindeki Etkileri”, 200.

25 Mektuptaki ifadeler için bkz. “Şeyh Fudaly Zokaydî” başlığı.

26 Zokaydî, Menâkıbu'l-vâlidi'l-üstad eş-Şeyh Mahmud ez-Zokaydî ve'l-cedd eş-Şeyh Abdulkahhar, 3. 
Ayrıca onun biyografisini içeren kısa bir risale de telif etmiştir. Yine Şeyh Ahmed-i Hânî́nin (ö.1119/1707 [?]) şark medreselerinde okutulan Nûbehârâ Biçûkân adlı eserine haşiyeler yazmıştır. Bunun yanı sıra mürşidi Şeyh Abdurrahman Tâğî́nin mektuplarını derlemiştir. ${ }^{27}$ Şeyhi Abdurrrahman Tâğî́nin 12 Zilhicce 1296/27 Kasım 1879 tarihinde kendisine gönderdiği bir mektupta şu nasihatler yer almaktadır:

“...Ey Allah yolundaki kardeş! Huzur nisbetini elde edene kadar rabitayı bırakma! Şu üç vakitte dikkatli ol: Konuşurken, yerken ve uyurken. Lezzetlere dalmayı bırak ve tefekkür içinde olmaya gayret et! Zira fani şeyleri kafirler arzular. Hakiki mahbuba yönel ki maksut ve matlup O'dur. Dostlarımıza karşı alçak gönüllü ol! Bizim adımıza Üstad Molla Ömer'in ve dedenizin [Molla Halil] evlatlarının elinden öp! Bizim yerimize onun kabrini ziyaret et! İmkân oldukça sohbete devam et ve her ne olursa olsun hiçbir şeyi sohbete denk tutma!.." 28

Şeyh Abdulkahhâr 1324/1906 yılında vefat etmiştir. ${ }^{29}$ Kabri Zokayd'da olup ziyaret edilmektedir. ${ }^{30}$ Müridi ve talebesi Molla Muhammed Zivingî, onun hatm-i hâcegânda okunan sıfatlarını şöyle yazmıştır:

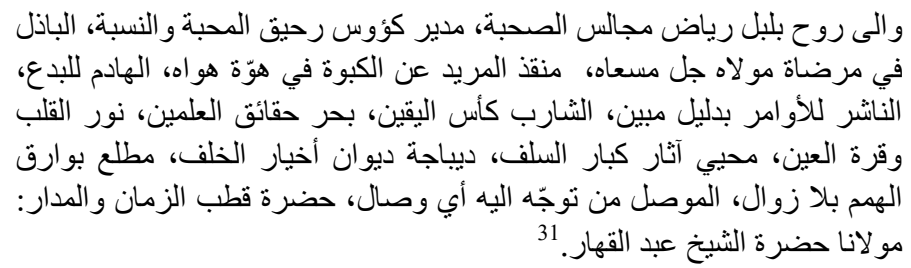

"Sohbet meclisi bahçelerinin bülbülü, nisbet ve muhabbet şarabının kadehini sunan, olanca çabasını Mevlâ'sının rızasında sarf eden, müridi nefsani arzular çukuruna düşmekten kurtaran, bidatleri yıkan, apaçık delil ile emirleri yayan, yakîn şarabından içen, iki ilmin hakikat denizi, kalbin nuru, göz bebeği, selef büyüklerinin eserlerini ihya eden, seçkin halef divanının dibacesi, himmet parıltılarının kesilmeyen kaynağı, kendisine yöneleni vuslata kavuşturan ki ne vuslat! Hazret-i kutbu'z-zemân ve'lmedâr Mevlânâ Hazreti eş-Şeyh Abdulkahhâr."

\footnotetext{
27 Zokaydî, Menâkıbu'l-vâlidi'l-üstad eş-Şeyh Mahmud ez-Zokaydî ve'l-cedd eş-Şeyh Abdulkahhar, 21.

28 Abdurrahman-1 Tâğî, Mektûbât, (Minah, İşarat ve diğer eserlerle ile birlikte derleyen Fudayl b. Şeyh Mahmud Zokaydî), 1373/1953, Süleymaniye Ktp., nr. 00650-001, 332; Abdurrahman-1 Tâhî [Tâğ̂̂], Mektûbât-l Seyda-i Tâhî, Çev. Ahmet Şahin, (İstanbul: Semerkand Yayınları, 2013), 203 (58. Mektup).

29 Zokaydî, Menâkıbu'l-vâlidi'l-üstad eş-Şeyh Mahmud ez-Zokaydî ve'l-cedd eş-Şeyh Abdulkahhar, 28.

30 Bkz. Ekler.

31 Zokaydî, Menâkıbu'l-vâlidi'l-üstad eş-Şeyh Mahmud ez-Zokaydî ve'l-cedd eş-Şeyh Abdulkahhar, 28-29.
} 


\section{B. Şeyh Mahmud Zokaydî (ö.1945)}

Şeyh Abdulkahhâr'ın oğlu olan Şeyh Mahmud, 1877 yılında Siirt'e bağlı Halenze (Bağtepe) köyünde dünyaya gelmiştir. Babası Şeyh Abdulkahhâr ve amcazâdesi Molla Hasan'ın (ö.1895) ${ }^{32}$ yanında ilim tahsil eden Şeyh Mahmud, ilmî icazetini babasından almıştır. Tasavvufî eğitimini ilk olarak babasından alan Şeyh Mahmud, daha kemale ermeden babası vefat edince mürşid arayışına girer. Bu maksatla Erzurum'da ikamet eden babasının pîrdaşı Şeyh Ahmed Taşkesenî́nin (ö.1909) yanına gitmek üzere yola koyulup yolda Bitlis'teki Norşin tekkesine uğrar. Burada akşam konaklarken Şeyh Alaeddin Ohinî (ö.1949) ile arasında geçen sohbet ve istişare neticesinde, Norşin'de postnişîn olan Şeyh Abdurrahman Tâğî́nin oğlu Şeyh Muhammed Diyauddin Norşinî́ye (ö.1924) bağlanmaya karar verir. Kısa sürede seyr u sülûkunu tamamlayan Şeyh Mahmud, tarikat hilafeti alır ve babas1nın irşad hizmetlerini devam ettirmek üzere Zokayd'a döner. ${ }^{33}$

Henüz şeyhi hayattayken irşad faaliyetlerine başlayan Şeyh Mahmud, Norşin ziyaretlerine de devam eder. Bu ziyaretlerinde zaman zaman şeyhinin iltifatlarına mazhar olur. Nitekim bir defasında Baykan'a bağlı Siyanis (Gümüşkaş) köyünde Şeyh Muhammed Diyauddin'i ziyaretinde, şeyhi sadece kendisi ve müridlerine yönelik teveccühte (mürşidin müridlere uyguladığ 1 bir tür manevi tedavi yöntemi) bulunmuştur. ${ }^{34}$ Şeyhiyle sıklıkla mektuplaşan Şeyh Mahmud, ondan tarikatın usul ve adabına dair tavsiyeler alır. Bu mektuplardan birinde Şeyh Muhammed Diyaudin, ona şu nasihatlerde bulunur:

“Ey kardeşim! Tarikatın maksadı, [kalbi] tasfiye ve tezkiye etmektir. Bu ikisinin hülasası; kulun kişisel menfaatine yönelik hiçbir şey yapmamasıdır. Hele dünya menfaatini hiç düşünmemelidir. Nefsin arzusu için yaptığı iş, uhrevî işlerine dönük olsa bile -Cenneti istemek ve Cehennemden sakınmak gibibundan uzak durmalıdır. Aksi takdirde bu kişi, bu tarikatın ehlinden sayılmaz. O zaman ey kardeş! Nefsini kontrol et! Onu Allah'a ihlaslı kıl ve başka her şeyden arındır."35

Şeyh Mahmud, medrese ve tekkeyle ilgilenirken; dönemin sosyal ve siyasal olaylarına kayıtsız kalmamıştır. Bu kapsamda ileride de bahsedileceği gibi I. Dünya savaşına katılmış ve Ruslara karşı mücadele vermiştir. Şeyh

\footnotetext{
Molla Halil'in en büyük oğlu Molla Mustafa'nın oğludur.

Zokaydî, Menâkıbu'l-vâlidi'l-üstad eş-Şeyh Mahmud ez-Zokaydî ve'l-cedd eş-Şeyh Abdulkahhar, 36-38.

Zokaydî, Menâkıbu'l-vâlidi'l-üstad eş-Şeyh Mahmud ez-Zokaydî ve'l-cedd eş-Şeyh Abdulkahhar, 55.

35 Muhamd Diyauddin Norşinî (Ahmed Haznevî ile birlikte), Mektûbât, Çev. Hasib Seven, (İstanbul: Yaylacık Matbaası, 1977), 111 (40. Mektup). Arşivimizdeki yazma nüshayla karşılaştırılıp çeviri metin tashih edilmiştir.
} 
Mahmud, 1922-1923'te büyük oğlu Molla Ahmed'in hastalığı sebebiyle Beyrut'a gitmiş ve burada sekiz aya yakın bir müddet kalmıştır. Beyrut'un birçok önemli âlimiyle tanışıp dost olan Şeyh Mahmud, bu seyahatteki hatıralarını es-Seyâha ilâ Beyrût adlı eserinde yazmıştır. ${ }^{36}$

Cumhuriyet döneminde meydana gelen 1925 Şeyh Said kıyamı ve ç1karılan tevhid-i tedrisat kanunu ile tekke ve zaviyelerin kapatılması kanunu neticesinde, medrese ve tekkeler birtakım baskılara maruz kalmıştır. Böyle bir ortamda birçok müderris ve şeyh sürgün edilirken, Şeyh Mahmud da sık sık karakola götürülerek Edirne' ye sürgün edilmekle tehdit edilmiştir. ${ }^{37}$ En nihayetinde Şeyh Mahmud, 1925 yılından itibaren bir yıl Antalya merkez, iki yıl da Korkuteli ilçesinde olmak üzere üç yıl sürgün hayatı yaşamıştır. Zokaydî, bu süre zarfındaki hatıralarını et-Teb'îd ilâ Antalya ve's-seyâha fî diyâri'l-İslâm adlı hatıratında yazmıştır. ${ }^{38} \mathrm{Bu}$ hatıratında bir dönem Antalya müftülüğü yapmış olan Ahmed Hamdi Okur (ö.1953) ile olan dostane ilişkilerinden bahseder. ${ }^{39}$ Sürgünden döndükten sonra 1940'lı yıllarda, yerel yönetimin baskılarından dolayı birkaç yıl Diyarbakır'da ikamet eder. Valinin tayini çıktıktan sonra Zokayd'a döner. ${ }^{40}$ Sürgün döneminde Said-i Nursî ile mektuplaşır. Bu mektupların birinde Nursî, onun şeyhini ve pîrdâşlarını şöyle metheder: Ben dostlarm, özellikle de Şeyh Muhammed Diyauddin'in firâkından [vefatından] dolayı gayet müteessirim. O, ay; sizler de yıldızsınız. Ay kaybolduğunda yıldızlarla yolumuzu buluruz. ${ }^{41}$

Çileli sürgün ve seyahatlerine rağmen Şeyh Mahmud bereketli bir ömür geçirmiştir. $\mathrm{O}$, bir taraftan irşad ile meşgul olurken, diğer taraftan da medresede dersler vermiştir. Bunun yanı sıra farklı alanlarda birçok eser telif etmiş ve hatırât yazmıştır. ${ }^{42}$ Eserleri genelde fıkıh, hadis usulü, tarih, edebiyat ve tecvid gibi alanlardadır. Eserleri şunlardır:

1. Hulâsatü'l-edeb fî mekârimi'l-ahlâki'l-me'sûre min seyyidi'l-'acem ve'l'arab

2. ed-Dâve'd-devâa

3. Şerhu'l-ma'fuvvât

\footnotetext{
36 Adnan Memduhoğlu, "Mahmud Zokaydî", Türkiye Diyanet Vakfi İslâm Ansiklopedisi (DİA), (İstanbul, Türkiye Diyanet Vakf1, 2016), EK-2, 180-181; Sevgili, “Şeyh Mahmud ez-Zokaydî ve ed-Dâ' ve'd-Deva' Adlı Eseri", 25-26.

37 Zokaydî, Menâkıbu'l-vâlidi'l-üstad eş-Şeyh Mahmud ez-Zokaydî ve'l-cedd eş-Şeyh Abdulkahhar, 46.

38 Zokaydî, Menâkıbu'l-vâlidi'l-üstad eş-Şeyh Mahmud ez-Zokaydî ve'l-cedd eş-Şeyh Abdulkahhar, 45.

39 Mahmud Zokaydî, et-Teb'îd ilâ Antalya ve's-Seyâha fî Diyâri'l-İslâm, (y.y., trsz.), 9, 13; Memduhoğlu, "Mahmud Zokaydî", 180-181.

40 Zokaydî, Menâkıbu'l-vâlidi'l-üstad eş-Şeyh Mahmud ez-Zokaydî ve'l-cedd eş-Şeyh Abdulkahhar, 46, 72.

41 Zokaydî, Menâkıbu'l-vâlidi'l-üstad eş-Şeyh Mahmud ez-Zokaydî ve'l-cedd eş-Şeyh Abdulkahhar, 46.

42 Zokaydî, Menâkıbu'l-vâlidi'l-üstad eş-Şeyh Mahmud ez-Zokaydî ve'l-cedd eş-Şeyh Abdulkahhar, 74.
} 
4. Şerh 'alâ Diyâ basîreti'l-kalbi'l-'arûffi't-tecvîd ve'r-resm ve ferşi'l-hurûf

5. İzâletü'ş-şübeh fî tezkiyeti'l-luhûm fi'l-İslâm

6. Hulâsatü'n-nuhbe fi fenni mustalahi'l-hadîs

7. Tevdîhu'l-mesâlik fî nesr Elfiyye İbn Mâlik

8. Ba'du mesâili't-talâki ve'l-eymân

9. Kitâbu âdâbi'l-hukûk ve hüsni's-suhbe

10. Risâle fi'l-ferâiz

11. Risâle fi'l-eymân

12. Risâle fî resmi'l-hatt

13. Risâletu'l-'arûziyye ve'l-kavâfiyye

14. Risâle fi't-telaffuz bi'd-dâd ve't-tâ

15. Târîhu ensâbi'l-enbiyâa

16. Kitâbu'l-hutab

17. et-teb'îd ilâ Antalya ve's-seyâha fî diyâri'l-İslâm

18. es-seyâha ilâ Haleb ve Beyrut

19. Kitâb fi'l-bahs 'an mesâili müteferrika

20. Risâle fî̀ ilmi't-tecvîd

21. Divan ${ }^{43}$

Tasavvufa dair müstakil bir eseri bulunmayan Şeyh Mahmud, Kitâbu âdâbi'l-hukûk ve hüsni's-suhbe adlı eserinde mürid-mürşid ilişkisi adabından bahseder. Yine ed-Dâ ve'd-devâa adlı eserinde sapkın tasavvuf ekollerinden söz eder. Bu kapsamda tasavvufu istismar eden sahte şeyhleri (müteşeyyih) eleştirir. Eleştirisinde şu çarpıcı ifadeleri kullanır:

“Ehl-i Sünnet arasında şeyhlik iddiasında bulunanlara gelince; Allah bizleri onlardan, onların fiillerinden, sözlerinden, hareketlerinden, duruşlarından, halkı gaflete düşürmelerinden, insanlardan mal toplamalarından, insanları doğru yoldan çıkarmalarından, Müslümanları saptırmalarından muhafaza etsin!

43 Eserler, Siirt'teki aile fertlerinin arşivinde muhafaza edilmektedir. Eserler hakkında daha fazla bilgi edinmek için bkz. Sevgili, "Şeyh Mahmûd Zokaydî́nin 'Kitâbu âdâbi'l-hukûki ve hüsni's-suhbe' Adlı Eseri Bağlamında Âdâb-1 Muâşeret ile İlgili Görüşleri”, 604-608. 
Aralarındaki kin ve nefreti anlatırsam, kalpler İslamiyet'ten nefret edecektir. Bunların her birine ait köylerden oluşan bölgeleri olup buralarda müridleri bulunmaktadır. Bu bölgeleri, kendi tapularıymış gibi görürler. Şeyh, genelde bunları dolaşır, çeşitli hile ve desiselerle mallarını toplar, dinden ve akıldan uzak nasihatte bulunur." 44

Öte yandan Ehl-i sünnet inancına sahip hakikî şeyhlerin bulunduğunu da belirten Şeyh Mahmud, bu nitelikteki kişilerin azlığından dem vurur. Bu durumla ilgili gözlemlerini şöyle aktarır:

“...[Gerçek şeyhler] zenginlik ve fakirliği, ilahi isimlerin tecellisinden bilip ayrım gözetmezler. Peygamberlerin ahlakı ile ahlaklanırlar. Sözleri tüm öldürücü zehirlerin panzehridir. Bu şeyhlerle daha önce bahsettiklerin arasındaki fark nedir? Şeklinde bir soru sorarsan, şunu derim: Aralarındaki fark açıktır. Zira şeriat terazisi elimizdedir. Söz ve davranışları şeriata uyanlar, evliyanın varisleri kısmına girerken; söz ve davranışları şeriata uymayanlar, Müslümanları kandıran, saptıran ve malları$\mathrm{n} 1$ alanlar ise şeytanın varisleridir. Belki şeytanın vekilleri kısmındandırlar. -İyi araştır ve onlardan sakın!- Peygamberin varisi olanlara canımızı, malımızı feda eder, bedenlerimizle onlara hizmet eder ve Allah'tan sayılarının artmasını dileriz. Ancak maalesef bu zamanda onlardan çok az kalmıştır. Onlar alacakarga ve kıymetli deve gibidirler ki onlarla herhangi bir kervanda karşılaşamazsın. İnna lillah ve inna ileyhi raciun... ${ }^{45}$

Şeyh Mahmud, 1364/1945 yılında vefat etmiş ve Zokayd'da babasının bulunduğu kabristanda defnedilmiştir. ${ }^{46}$ Vefatından bir yıl önce vasiyetnâmesini hazırlamıştır. Bu vasiyetnamede; kendisinden sonra aile fertlerine sırasıyla oğulları Şeyh Haydar, Şeyh Masum ve Şeyh Cüneyd'i vasî tayin etmiştir. ${ }^{47}$ Yine mezar şâhidesinin bir tarafına Hâfız Şîrâzî́nin şu beytinin yazılmasını vasiyet etmiştir:

خدا را رحمى اى منعم كه درويش سر كويت درى ديكر نمى داند رهى ديكر نمى كيرد

Ey Mün'im! Allah aşkına kapında dolaşana merhamet et! Bundan başka ne bir kapı ne bir yol biliyor.

Mezar şâhidesinin diğer tarafına da Bahâeddin Şâh-1 Nakşibend'in (ö.791/1389) aşağıdaki beytinin yazılmasını vasiyet etmiştir:

\footnotetext{
44 Mahmud Zokaydî, ed-Dâ ve'd-devâ, (y.y., trsz.), 49; Sevgili, “Şeyh Mahmud ez-Zokaydî ve 'ed-Dâ've'dDeva' Adlı Eseri", 120.

45 Zokaydî, ed-Dâve'd-devâ, 50; Sevgili, “Şeyh Mahmud ez-Zokaydî ve 'ed-Dâ've'd-Deva' Adlı Eseri”, 122.

46 Zokaydî, Menâkıbu'l-vâlidi'l-üstad eş-Şeyh Mahmud ez-Zokaydî ve'l-cedd eş-Şeyh Abdulkahhar, 32.

47 Zokaydî, Menâkıbu'l-vâlidi'l-üstad eş-Şeyh Mahmud ez-Zokaydî ve'l-cedd eş-Şeyh Abdulkahhar, 84.

48 Hâfız Şîrâzî, Dîvân-ı Hâfiz, (Tahran: İntişârât-ı Kitâb âbân, 2010), 153, (Gazel: 149).
} 


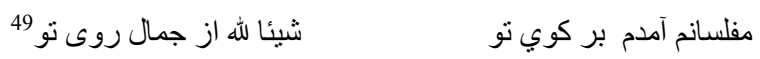
lütfet!

Iflas etmiş biriyim kapına geldim. Allah için yüzünün cemalinden bir şeyler

Şeyh Mahmud'un yedi erkek çocuğu vardı. Bunların hepsi de medrese tahsili görmüş ve tedris faaliyetleriyle iştigal etmiştir. Bunların isimleri Ahmed, Haydar, Masum, Cüneyd, Selâhaddin, Fudayl ve Yahyâ'dır. ${ }^{50}$ Çalışmamızın bundan sonraki bölümünde, tekke ve medrese faaliyetleriyle ön planda olan Şeyh Haydar, Şeyh Cüneyd ve Şeyh Fudayl'i ele alacağız.

\section{C. Şeyh Haydar Zokaydî (ö.1966)}

Şeyh Mahmud vefat ettikten sonra vasiyeti üzere Zokayd tekkesi ve medresesini oğlu Şeyh Haydar idare eder. 1899 yılında Zokayd'da doğan Şeyh Haydar, ilk tahsilini Zokayd medresesinde müderris Molla Nasreddin'den (Seven) (ö.1935) alır. Daha sonra babası Şeyh Mahmud'un yanında tahsilini tamamlayıp ilmî icazetini aldıktan sonra medresede müderrislik yapar. Müderrislik yaptı̆̆ dönemde Seyyid Ahmet ve Şeyh Resul Bışerîye (Beykent) ilmî icazet verir. Şeyh Haydar, babası Şeyh Mahmud'un 1922'deki Beyrut seferi ve 1925-1928 yılları arasındaki Antalya'ya sürgünü sırasında ailenin sorumluluğunu üstlenir. ${ }^{51}$

Tasavvufî eğitimini öncelikle babasından alır. Babasının vefatından sonra Norşin'de postnişîn olan Mela-yi Mezin (Büyük Molla) namıla bilinen Muhammed Emin Kursincî́nin (ö.1933) halifelerinden Şeyh Muhammed Bakîye (ö.1972) intisap eder. İki yıl seyr u sülûk ettikten sonra kendisinden hilafet alır. Şeyh Haydar döneminde siyasi baskılar nispeten azaldığından irşad faaliyetleri daha rahat bir ortamda yürütülür. Kayda değer irşad hizmetlerinden biri, Siirt'e bağlı Kutmıs (Yerlibahçe) köyündeki gayrimüslimleri İslam'a davet etmesidir. Bu davet vesilesiyle köydeki Hiristiyanların büyük bir kısmı Müslüman olmuştur. Oğlu Şeyh Mazhar'ın (ö.1980) bildirdiğine göre; Zokayd medresesi müderrislerinden Molla Abdussamed Comanî (Bilgin) (ö.1993), Şeyh Haydar'dan tarikat icazeti almıştır. Bu bilgiye dayanak olarak, Molla Abdussamed ile Şeyh Haydar'ın mektuplaşmalarında geçen bazı ifadelerin hilafeti ima ettiği gösterilmiştir. Şeyh Haydar, 1966 yılında vefat etmiştir. Kabri Zokayd'da babasının yanındadır. ${ }^{52}$

\footnotetext{
49 Bahaeddin Şah-ı Nakşibend vefat edeceği zaman, cenazesinde bu beytin okunmasını vasiyet etmiştir. Bkz. Abdurrahman Câmî, Nefehâtü'l-üns min hazarâti'l-kuds, tsh. ve ta'lik Mahmud Âbidî, (Tahran: İntişârât-1 İttilâ'ât, 1370 h.ş.), 393.

50 Zokaydî, Menâkıbu'l-vâlidi'l-üstad eş-Şeyh Mahmud ez-Zokaydî ve'l-cedd eş-Şeyh Abdulkahhar, 81.

51 Sevgili, "Şeyh Mahmud ez-Zokaydî ve 'ed-Dâ' ve'd-Deva' Adlı Eseri”, 34.

52 Sevgili, "Şeyh Mahmud ez-Zokaydî ve 'ed-Dâ' ve'd-Deva' Adlı Eseri”, 34.
} 


\section{D. Şeyh Cüneyd Zokaydî (ö.1963)}

Şeyh Mahmud'un oğulları arasında en aktif olanı, tekke ve medresedeki hizmetleriyle Şeyh Cüneyd olmuştur. Şeyh Cüneyd, 1911 yılında Zokayd'da doğmuştur. Medrese tahsilini babası Şeyh Mahmud'un yanında ikmal etmiştir. ${ }^{53}$ Tasavvufî eğitimini ilk olarak babası Şeyh Mahmud'dan alan Şeyh Cüneyd, onun vefatından sonra beş yıl Şeyh Alaeddin Ohinî́nin (ö.1949) yanında seyr u sülûka devam etmiştir. Onun da vefat etmesiyle 1950' nin başlarında Şeyh Muhammed Diyauddin'in halifelerinden Suriye'de bulunan Şeyh Mahmud-i Karakoyî́nin (ö.1952) nezdinde iki yıl daha eğitimine devam edip hilafet almıştır. ${ }^{54}$

Hilafet aldıktan sonra Zokayd'a dönen Şeyh Cüneyd, medresede ders vermenin yanı sıra vefatına kadar yaklaşık on iki yıl halkı irşadla meşgul olmuştur. ${ }^{55}$ Zahidâne hayatıyla tanınan Şeyh Cüneyd -diğer Zokayd şeyhleri gibi- merkez tekke Norşin ve onun yakınındaki Ohin tekkesindeki âlim ve şeyhlere ihtimam vermiş ve onlara ayrı bir muhabbet beslemiştir. Bu muhabbetinin bir tezahürü olarak, vefat edeceği zaman bir dönem tasavvufî eğitim aldığı mürşidi Şeyh Alaeddinin oğlu Şeyh Hâlid Ohinî onu ziyarete geldiğinde, ayaklarının dibinde oturduğunu görmüş ve yanındakilere ısrarla kendi yönünün değiştirilmesini istemiştir. ${ }^{56}$

Hattatlı̆̆ıla da meşhur olan Şeyh Cüneyd, pek çok medrese kitaplarını istinsah etmiş ve birçoğuna da haşiye ve talikler eklemiştir. Ayrıca büyük dedesi Molla Halil ve babası Şeyh Mahmud'un eserlerini istinsah ederek bu eserlerin sonraki nesillere ulaşmasına katkıda bulunmuştur. Bunun yanı sıra kendi silsilesindeki bazı meşayihin mektup ve eserlerini de istinsah etmiştir. ${ }^{57}$ Şeyh Cüneyd, 1963 yılında erken denilebilecek bir yaşta, 52 yaşında vefat eder ve Zokayd'da babası ile dedesinin bulunduğu kabristanda defnedilir. Kardeşleri Şeyh Fudayl ile Şeyh Selahaddin (ö.1981) onun hakkında Kürtçe mersiye yazmışlardır..$^{58}$

\section{E. Şeyh Fudayl Zokaydî (ö.1992)}

Şeyh Mahmud'un oğlu Şeyh Fudayl, 1919'da Zokayd'da doğmuştur. Medresede okutulan üst seviyedeki kitapların eğitimini babası Şeyh Mah-

\footnotetext{
3 Adak, "Şeyh Cüneyd-i Zokaydî ve Mahtut Bir Şiir Mecmuası", 133.

54 Adak, "Şeyh Cüneyd-i Zokaydî ve Mahtut Bir Şiir Mecmuası", 134.

55 Adak, "Şeyh Cüneyd-i Zokaydî ve Mahtut Bir Şiir Mecmuası", 134.

56 Sevgili, "Zokayd Medrese ve Tekkesinin Veysel Karenî Yöresindeki Etkileri”, 207-208.

57 Adak, "Şeyh Cüneyd-i Zokaydî ve Mahtut Bir Şiir Mecmuası", 134. Örneğin, Şeyh İbrahim Çokreşî’nin İşârât adlı eseri ile Şeyh Abdurrahman Tâğî̀nin mektuplarını istinsah etmiştir. Bu nüshalar Siirt'teki torunlarında muhafaza edilmektedir.

58 Sevgili, “Şeyh Mahmud ez-Zokaydî ve 'ed-Dâ' ve'd-Deva' Adlı Eseri”, 36.
} 
mud'dan almakla birlikte, tahsilinin büyük kısmını ağabeyi Şeyh Cüneyd'de tamamlamıştır. İlmî icazetini de hem babasından hem de ağabeyinden almıştır. ${ }^{59}$ Tasavvufî eğitime Zokayd' da babasının yanında başlamış, hilafetini ise dönemin Norşin şeyhlerinden Şeyh Maşuk Norşinî́den (ö.1975) almıştir. ${ }^{60}$

Şeyh Fudayl, tekkesinde oturan bir şeyh profilinden ziyade, etraftaki köyleri gezerek irşadda bulunan, insanlarla hemhal olan bir mürşid kimliğiyle ön plandadır. Yaklaşık kırk beş yıl Garzan bölgesindeki köyleri dolaşarak insanları irşad eden Şeyh Fudayl, bölgedeki birçok caminin inşası ve onarılmasında da ön ayak olmuştur. ${ }^{61}$

Babasının vefatından sonrasına denk gelen tarihlerde askerî göreve giden Şeyh Fudayl, burada yaşadıklarını hatıralarında kaydetmiştir. Buna göre; İstanbul Yıldız Sarayı' nda bir buçuk yıl, Süleymaniye kışlasında da altı ay askerlik yapmıştır. Üç ay hava değişimi aldıktan sonra ise Bingöl'ün Kığı ilçesinde askerliğine devam etmiştir. ${ }^{22}$ Şeyh Fudayl da babası Şeyh Mahmud gibi Said-i Nursî ile irtibatlı olmuş ve onunla mektuplaşmıştır. Onun Şeyh Fudayl'a gönderdiği bir mektubu incelediğimizde, Nursî́nin Zokayd şeyhlerine olan saygısını ön planda görmekteyiz. Bu husus, mektuptaki şu ifadelerde beyan edilmiştir:

“...Şeyh Abdulkahhâr, benim üstadlarımdan pek kudsi bir üstadımdır. Hem o, hem mübarek, merhum, mahdum Şeyh Mahmud her sabah benim üstadlarım, kardeşlerim içinde okuduklarımı ruhlarına hediye ediyorum. Ve bugünden itibaren, hem Fudayl hem kardeşleri, hem Zokayd'daki fakahları [talebeler], nur talebeleri içinde dualarımı ve okuduklarımı da onların ruhlarına vermeye karar verdim..." 63

Genelde biyografi ve hatırat tarzı eser yazan Şeyh Fudayl, babası ve dedesinin hayat ve menkıbelerine dair Menâkıbu'l-vâlidi'l-üstad eş-Şeyh Mahmud ez-Zokaydî ve'l-cedd eş-Şeyh Abdulkahhâr adlı eseri telif etmiştir. ${ }^{44}$ Mürşidi Şeyh Maşuk'un babası Şeyh Masum Norşinî́nin hayatını da kaleme alan Şeyh Fudayl, gittiği hac ziyaretine dair günlük tutmuştur. Ayrıca bölgedeki birçok âlim ve meşayihin eser ve mektuplarını istinsah edip derleyerek son-

\footnotetext{
59 Zokaydî, Menâkıbu'l-vâlidi'l-üstad eş-Şeyh Mahmud ez-Zokaydî ve'l-cedd eş-Şeyh Abdulkahhar, 67.

60 Sevgili, “Zokayd Medrese ve Tekkesinin Veysel Karenî Yöresindeki Etkileri”, 210.

61 Sevgili, "Zokayd Medrese ve Tekkesinin Veysel Karenî Yöresindeki Etkileri”, 210.

2 Zokaydî, Menâkıbu'l-vâlidi'l-üstad eş-Şeyh Mahmud ez-Zokaydî ve'l-cedd eş-Şeyh Abdulkahhar, 68-69.

3 Sevgili, "Zokayd Medrese ve Tekkesinin Veysel Karenî Yöresindeki Etkileri”, 213.

64 Çalışmamızın birincil kaynaklarından olan bu eserde, adı geçen şeyhlerin birçok kerameti dikkat çekicidir. Eser mahtût olup doksan beş sayfadır.
} 
raki nesillere ulaşmasına katkıda bulunmuştur. ${ }^{65}$ Şeyh Fudayl, 1992 yılında vefat etmiş ve Zokayd'a dedesinin yanına defnedilmiştir. ${ }^{66}$

\section{Zokayd Medresesi ve Medresede Yetişen Âlimler}

Şeyh Abdulkahhâr, 1880'li yılların başında Garzan'a bağlı Zokayd köyüne yerleştiğinde, burada tasavvufî faaliyetlerin yanı sıra tedris faaliyetlerini yürütmek için tekkenin yanına bir medrese inşa eder ve kendisi bizzat burada ders vermeye başlar. Zokayd ve çevresinden birçok talebenin rağbet ettiği bu medrese, kısa zamanda bölgenin gözde medreselerinden biri olarak kabul görür. ${ }^{67}$ Zokayd'ın günümüze kadar uzanan tarihi süreci değerlendirildiğinde medresedeki faaliyetlerin tekkeye göre daha baskın olduğu söylenebilir. Bunun en açık göstergesi, bu medresede yüzlerce âlim yetişmesine rağmen -bilindiği kadarıyla- tekkede halifelerin yetişmemesidir. Bununla birlikte buradaki yetişen âlimler hilafet almasalar bile tasavvufî meşrebi benimseyen sûfî-âlimler olarak nitelenebilir. Zokayd şeyhlerinin medrese faaliyetlerine ağırlık vermesinin arka planında ise mensubu oldukları Molla Halil ailesinin medreseye verdiği ihtimamın bulunduğu kuşkusuzdur.

Medresenin kurucusu ve ilk müderrisi olan Şeyh Abdulkahhâr'ın yetiştirdiği âlimler hakkındaki bilgiler sınırlıdır. Bunlardan biri, şeyh olmadan önce de talebesi olan Şeyh Abdülhakim Ceznî́dir. Nitekim kaynaklarda Şeyh Abdülhakim onun sadık bir talebesi olarak anılmaktadır. ${ }^{68}$ Kaynaklarda talebesi olarak geçen bir diğer kişi ise Molla Muhammed Zivingî́dir. Aynı zamanda müridi de olan Zivingî, Suriye' de sınır hattında yer alan Kamışlı kazasında bir dönem müftülük yapan ve Melâyê Cizirî́nin divanına şerh yazan meşhur Molla Ahmed Zivingî́nin babasıdır. ${ }^{69}$

Zokayd tekkesine Şeyh Mahmud postnişîn olduğunda ise medresede bizzat ders vermekle birlikte başka müderrisleri de görevlendirmiştir. ${ }^{70}$ 1318/1900 maarif salnâmesine göre Zokayd medresesinin müderrisi "Mahmud Efendi" olarak gösterilmiş ve talebe sayısı da 30 kişi olarak kaydedil-

65 Sevgili, "Zokayd Medrese ve Tekkesinin Veysel Karenî Yöresindeki Etkileri”, 211-212. Birçok farklı eserin yer aldığı iki yüz küsur varak eserler mecmuasının bir kopyası Süleymaniye Ktp., Özel Bölüm, nr. 650/1'de yer almaktadır. Bu eserler arasında, Seyyid Sıbgatullah Arvasî́nin Minah'1, Şeyh İbrahim Çokreşî́nin İşârât'ı, Şeyh Abdurrahman Tâğ̂în nin Mektûbât'1 ve Şeyh Fethullah Verkanisî́nin Mektûbât' 1 bulunmaktadır.

66 Sevgili, "Zokayd Medrese ve Tekkesinin Veysel Karenî Yöresindeki Etkileri”, 212.

67 Sevgili, "Şeyh Mahmud ez-Zokaydî ve 'ed-Dâ' ve'd-Deva' Adlı Eseri", 6.

68 Zokaydî, Menâkıbu'l-vâlidi'l-üstad eş-Şeyh Mahmud ez-Zokaydî ve'l-cedd eş-Şeyh Abdulkahhar, 5.

69 Zokaydî, Menâkıbu'l-vâlidi'l-üstad eş-Şeyh Mahmud ez-Zokaydî ve'l-cedd eş-Şeyh Abdulkahhar, 28. Bölgede Molla Muhammed Zivingî (ö.1971) adında son dönemde yetişen bir âlim daha vardır. Ancak Şeyh Abdulkahhar' in talebesi olan Molla Muhammed Zivingî daha önceki bir dönemde yaşayan bir zat olup ikincisinden farklı biridir.

70 Zokaydî, Menâkıbu'l-vâlidi'l-üstad eş-Şeyh Mahmud ez-Zokaydî ve'l-cedd eş-Şeyh Abdulkahhar, 38. 
miştir. ${ }^{71}$ Cumhuriyet döneminde Tevhid-i tedrisat kanunuyla birlikte medreseler kapatılınca, Şeyh Mahmud'un önderliğinde Zokayd medresesi, köyde bulunan yer altındaki bir mescitte gizlice eğitim vermeye devam etmiştir. ${ }^{72}$ Sürgün hayatı yaşamasına rağmen Şeyh Mahmud döneminde Zokayd'da birçok âlim yetişmiştir. Onun döneminde ve sonrasında bu medresede müderrislik yapan bazı kişiler şunlardır: Şeyh Mahmud'un çocuklarından Şeyh Haydar, Şeyh Cüneyd, Şeyh Fudayl; Şeyh Mahmud'un talebelerinden Molla Nasreddin, Molla Ali, Molla Muhammed (Özlük) (ö.1977) ve Molla Emin (Seven) (ö.1972). Daha sonraki dönemlerde müderrislik yapanlar arasında Şeyh Haydar'ın oğlu Şeyh Mazhar (ö.1980) ile Şeyh Masum'un oğlu Molla Zeki (ö.2003), Şeyh Selahattin'in oğlu Şeyh Selim, Molla Bedreddin (Seven) (ö.2006), Molla Abdülmecit (Seven) (ö.2007) ve Molla Muhammed Evcil (ö.1994) yer almaktadır.73

Şeyh Mahmud'un icazet verdiği âlimler şunlardır: Molla Nasreddin (Seven), Şeyh Haydar, Molla Ali (Eviz), Şeyh Cüneyd, Şeyh Fudayl, Molla Abdussamed Comanî, Molla Resul (Özlük) (ö.1940), Molla Muhammed (Özlük) ve Molla Emin (Seven). ${ }^{74}$

Medrese faaliyetleriyle ön planda olan bir diğer kişi Şeyh Cüneyd'dir. Babasıyla birlikte Diyarbakır'daki yaklaşık üç yıllık ikameti dışında, ömrünün geri kalan kısmını Zokayd medresesinde tedrîsat ile geçiren Şeyh Cüneyd döneminde, Zokayd medresesi şöhretine şöhret katar. Şeyh Cüneyd, Zokayd'a döndükten sonra vefatına kadar yirmi beş yıl müderrislik yapmıştır. Talebelerine ders verirken bir muhakkik gibi çok titiz davranan Şeyh Cüneyd, diğer müderrislere göre daha az talebeye ders vermiştir. ${ }^{75}$

Şeyh Cüneyd, Zokayd'da onlarca talebe yetiştirmiştir. Bunların bir kısmı kendisinden icazet almış; diğer bir kısmı ise bir müddet kendisinde ders okumuştur. Ondan icazet alanların bazısı şunlardır: Şeyh Fudayl, Şeyh Mazhar (yeğeni), Şeyh Selim (yeğeni), Molla Behçet (yeğeni), Seyyid Ömer Zınafî, Molla Musa İspandikî, Molla Sedik Beykendî, Molla Hüseyin Kulpikî ve Molla Ali Aynî. Şeyh Cüneyd'den ders alıp icazet almayan talebelerinden bazısı ise şunlardır: Şeyh Selahaddin (kardeşi), M. Halil Günenç, ${ }^{6}$ Diyarbakırlı Molla Seyyaf, Molla Haydar Hatipoğlu, Hazrolu M. Said Ergin, Diyar-

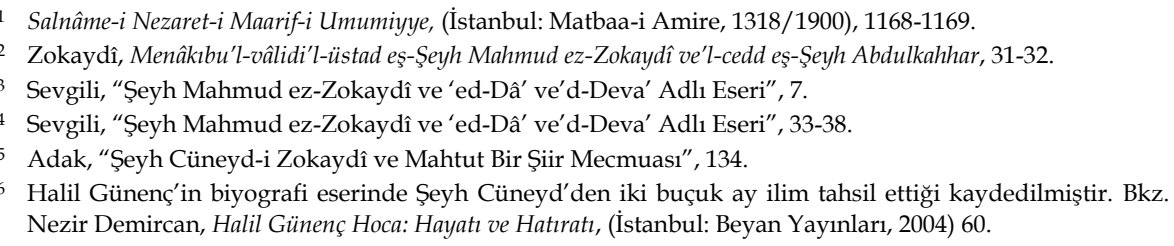


bakırlı Molla Tayfur, Şeyh Hafîd Eren, Mardinli Molla Nâvî ve Molla İsmet (yeğeni). ${ }^{77}$

Zokayd medresesinin son dönemlerinde etkin bir biçimde tedrisle iştigal edenlerin başında Şeyh Fudayl gelmekteydi. Vefat ettiği 1992 yılına kadar müderrislik yapan Şeyh Fudayl onlarca âlim yetiştirmiştir. Kendisinden icazet alanların bazısı şunlardır: "Molla Bedreddin Zokaydî, Molla Muhammed Can Bevasî, Molla Reşid Comanî, Molla Sadreddin Kulerî, Molla Sadik Sihî, Molla Resul Sihî, Molla Muhammed Comanî, Molla Esad Batranî, Molla Muhammed Batranî, Molla Nasreddin Comanî, Molla Mustafa Şemsî, Molla Zeynelabidin Comanî, Molla Sibgatullah Zokaydî (Sevgili). ${ }^{78}$ Günümüzde medrese faaliyetlerini Şeyh Fudayl'in oğlu Molla Sıbgatullah Sevgili yürütmektedir.

Bölgede birçok medrese olmakla birlikte Zokayd medresesini diğerlerinden ayıran bazı özelliklerden bahsedilebilir. Buna göre; bu medresede diğerlerine göre şiir ve hat sanatlarına daha çok ilgi gösterilmiştir. Nitekim şeyhlerin divan eserlerinin bulunması ve birçok kitabı istinsah etmeleri bunu göstermektedir. Yine Zokayd medresesinde Farsça talimi yapılmakla birlikte, Sadi Şîrâzî̀nin Gülistân ve Bostân'ı, Abdurrahman Camî'nin Baharistân'ı ile Hâfız Şîrâzî̀nin Divân'ı gibi tasavvuf klasikleri okutulmuştur. Dikkat çeken bir diğer özellik de kıraât ilmine önem verilmesi ve tecvid derslerinin okutulmasıdır. ${ }^{79}$

\section{Tekkenin Dini-Sosyal Etkileri}

\section{A. Yezîdî Batran Köyünün Müslümanlaşması}

XIX. yüzyılda bölgedeki diğer illerde olduğu gibi Siirt'te de farklı inançlara mensup insanlar bulunmaktayd. 1310/1892 Bitlis salnâmesine göre, Garzan ilçesinde 18.518 nüfus varken bunun 6000 civarını; Ermeni, Katolik, Protestan, Süryani ve Yezîdîler oluşturmaktaydı. ${ }^{80}$ Bunlar içerisinde Yezîdî nüfus 1269 olarak kaydedilmiştir. ${ }^{81}$

\footnotetext{
Sevgili, "Zokayd Medrese ve Tekkesinin Veysel Karenî Yöresindeki Etkileri”, 208-209.

Sevgili, "Zokayd Medrese ve Tekkesinin Veysel Karenî Yöresindeki Etkileri”, 212.

79 Sevgili, “Şeyh Mahmud ez-Zokaydî ve 'ed-Dâ' ve'd-Deva' Adlı Eseri”, 16-17.

80 Salnâme-i Vilâyet-i Bitlis, (Bitlis: Bitlis Vilayet Matbaası, 1310/1892), 280 [?]. Aynı salnâmede Siirt merkez nüfusu 18.979 olarak gözükmektedir. Bu da Garzan'ın o dönemlerde Siirt merkez kadar bir nüfus yoğunluğuna sahip olduğunu göstermektedir.

81 Salnâme-i Vilâyet-i Bitlis, 280 [?]. Nüfus tablosu için bkz. Ebru Polat, "H. 1310 (M. 1892) ve H. 1316.1317.1318 (M. 1898.1899.1900) Tarihli Bitlis Vilâyeti Sâlnâmelerinin Transkripsiyon ve Değerlendirmesi", (Yayınlanmamış Yüksek Lisans Tezi, Erciyes Üniversitesi Sos. Bil. Enst., Kayseri 2006), 182.
} 
Şeyh Abdulkahhâr'ın irşadda bulunduğu bölgede Yezîdîler ${ }^{82}$ de yaşamaktaydı. Şeyh, halkı Yezîdî olan Batran (Kurtalan/Yellice) köyüne yaptığı ziyaretlerdeki irşadı neticesinde, köy halkının Müslüman olmasına vesile olmuştur. Şeyh Fudayl'in bildirdiğine göre; bu irşad kapsamında Şeyh Abdulkahhâr, Yezîdîlerin saygı gösterdiği Şeyh 'Adî b. Müsâfir'i (ö.557/1162) över ve onun büyük bir veli olduğundan bahsederdi. ${ }^{83}$ Buradan hareketle, Yezîdîlerin Müslümanlaşmasında; Şeyh Abdulkahhâr'ın, 'Adî b. Müsâfir'in sünnî inanca sahip olduğunu onlara anlatması ihtimalinin etkisinden söz edilebilir. Öte yandan bu durum, farklı inançlarda olsa bile bir sûfînin iletişim kurmak için ortak nokta arayışı çabasını da göstermektedir.

Batran halkı Müslüman olunca, Şeyh Abdulkahhâr burada bir mescid ve mektebin inşa edilmesine çaba sarf etmiştir. Şeyh Fudayl'in bildirdiğine göre; buradaki mescidin inşasına Sultan II. Abdülhamid (ö.1918) bizzat yardımda bulunmuş ve onun annesi Valide Sultan da bu mescide kıymetli bir halı hediye etmiş̧ir. ${ }^{84}$ Bunu teyid eden bilgiler, 1310/1892 Bitlis salnâmesinde de yer almaktadır. Salnâmede, iki-üç yıl önce (1889-1890) Batran köyündeki mescid ve mektebin inşasının bizzat padişahın yardımlarıyla yapıldığı kaydedilmiştir. ${ }^{85}$ Yine Osmanlı arşiv kayıtlarında bu mescid ve mektebin inşasıyla ilgili birtakım belgelere rastlanmıştır. Bu belgelerle birlikte mescid ve mektebin krokisi de yer almaktadır. ${ }^{86}$ Belgenin başında geçen ifadeler şöyledir:

"Siird sancağına mülhak Garzan kazası dâhilinde olub mukaddemen bil-ihtida şeref-i din-i İslam ile müşerref olan Batrî [Batran] nam Yezîdî karye ahalisinden otuz nüfus [...] hayat-1 İslamîlerini takrir ve teyidi içun karye-i mezkurede inşası elzem olan bir bab camii şerif ile mektebin inşası hakkında..." 87

Öte yandan 1318/1900 Maarif salnâmesinde, Batran köyünde dini ilimlerin öğretildiği medrese kaydı bulunmaktadır. Medresenin bânisi hakkında "taraf-1 eşref-i hazreti padişahiden inşa ettirilmiştir." notu düşülmüş-

\footnotetext{
82 Zerdüştîlik, Yahudilik, Hıristiyanlık ve İslam'dan etkilenen senkretik bir inanç istemidir. Ayrıca bu inançtan olup özellikle Adî b. Müsafir'e saygı gösteren topluluklarda tasavvufun da etkisi görülmektedir. "Yezîdî" nisbesi hakkında birçok görüş olsa da son araştırmalar bu ismin I. Yezîd'le yakın ilgisini ortaya koymaktadır. Bu inancın merkezinde Tanrı ile birlikte yedi melek ve bu melekleri idare eden Melek Tâvus bulunmaktadır. Kutsal kitapları ise Kitâbü'l-Celve ile "siyah kitap" anlamındaki Mushaf-ı Reş'tir. Bkz. Ahmet Taşğın, "Yezîdiyye" Türkiye Diyanet Vakfi İslâm Ansiklopedisi (DİA), (İstanbul, Türkiye Diyanet Vakf1, 2013), XXXXIII, 525-527.

83 Zokaydî, Menâkıbu'l-vâlidi'l-üstad eş-Şeyh Mahmud ez-Zokaydî ve'l-cedd eş-Şeyh Abdulkahhar, 6.

84 Zokaydî, Menâkıbu'l-vâlidi'l-üstad eş-Şeyh Mahmud ez-Zokaydî ve'l-cedd eş-Şeyh Abdulkahhar, 8.

85 Salnâme-i Vilâyet-i Bitlis, 238.

86 Bkz. Ekler.

87 BOA, A.MKT.MHM., Doya No: 501 Gömlek No: 30, Tarih: H 22 03 1308/5 Kasım 1890.
} 
tür. Medresenin mevcudu altı talebe olup müderrisi Abdullah Efendi'dir. ${ }^{88}$ Kendi köyleri ve Zokayd gibi civar köylerdeki medreselerde ilim tahsiline yönelen Batran halkından birçok âlim yetişmiştir. Bu âlimler arasında Molla Esad Batranî, Molla Muhammed Batranî ve Molla Necmeddin Batranî bulunmaktadır. ${ }^{99}$ Şeyh Fudayl'in bildirdiğine göre; yıllar sonra Batran'daki mescid ve medrese tamirata ihtiyaç duyduğunda buradaki yapıların onarımina kendisi öncülük etmiştir. ${ }^{90}$

\section{B. Kıtlıkta Yapılan Yardımlar ve Kimsesizlerin Gözetilmesi}

Tekkelerin fonksiyonlarından biri de özellikle olağanüstü durumlarda insanî yardımlarda bulunması ve insanların temel ihtiyaçlarını karşılamasıdır. Bu kapsamda kıtlıkta tekkeler birer aşevine dönüşebilmektedir. I. Dünya savaşından sonra Anadolu'da büyük bir kıtlık baş göstermişti. Zokayd tekkesinin bulunduğu Garzan bölgesinde de insanlar yiyecek bulmakta zorlanıyordu. Böyle bir ortamda Zokayd tekkesi bir aşevi işlevi görüp insanların karınlarını doyurduğu bir merkez olmuştur. Tekke, hiç kimseyi ayırt etmeksizin hizmetlerini sürdürmüş ve bir nebze de olsa bu sıkıntıya çare olmaya çalışmıştır. Bu kıtlıktan farklı olarak yine 1940-46 yıllarında oluşan kitlıkta da tekke aynı şekilde insanlara yiyecek temin etmiş ve bu yiyeceğin dağıtıminda Şeyh Mahmud bizzat kendisi hizmet etmiştir. ${ }^{91}$

Ermeni tehciri ile bölgedeki Ermeniler sürgün edildiğinde birçok Ermeni çocuğu sahipsiz kalmıştı. Aile mensuplarının anlattığına göre; Şeyh Mahmud, kimsesiz olan bu Ermeni çocukların bakımını üstlenmiş ve evlenene kadar himaye etmiştir. Neticede Zokayd tekkesi bu faaliyetiyle, o dönemdeki sosyal buhranın neden olduğu soruna çözüm üretmekten çekinmemiş ve mağdur kimselere yardım etmeye çalışmıştır. Bu kapsamda Abid Sevgili, bu kimsesiz çocuklardan bazılarının isimlerini kendi eserinde zikretmiştir. ${ }^{92}$ Yine Şeyh Mahmud, I. Dünya savaşından sonra Garzan bölgesine hicret eden kimselere yardım etmiş ve onların Zokayd'da yer edinmesinde kolaylıklar sağlamıştır. ${ }^{93}$

\footnotetext{
88 Salnâme-i Nezaret-i Maarif-i Umumiyye, (İstanbul: Matbaa-i Amire, 1318/1900), 1169. Salnâmede Batran "Nazran" olarak kaydedilmiştir.

89 Sevgili, "Zokayd Medrese ve Tekkesinin Veysel Karenî Yöresindeki Etkileri", 212.

90 Zokaydî, Menâkıbu'l-vâlidi'l-üstad eş-Şeyh Mahmud ez-Zokaydî ve'l-cedd eş-Şeyh Abdulkahhar, 8.

91 Zokaydî, Menâkıbu'l-vâlidi'l-üstad eş-Şeyh Mahmud ez-Zokaydî ve'l-cedd eş-Şeyh Abdulkahhar, 43-44, 47.

92 Sevgili, "Şeyh Mahmud ez-Zokaydî ve 'ed-Dâ' ve'd-Deva' Adlı Eseri”, 23.

93 Sevgili, "Şeyh Mahmud ez-Zokaydî ve 'ed-Dâ' ve'd-Deva' Adlı Eseri”, 24.
} 


\section{Tekkenin Sosyo-Politik İlişkileri}

\section{A. Bölgedeki Arabuluculuk Rolü}

Zokayd'ın bağlı olduğu Garzan kazasında birçok aşiret bulunmaktaydı. Bu aşiretler kendi aralarında olduğu gibi devlet ile de zaman zaman sorunlar yaşıyordu. Zokayd şeyhleri, bu gibi durumlarda arabulucu rolü üstleniyor ve sorunun çözülmesinde etkin olabiliyordu. Nitekim arşivde yer alan şifreli bir telgrafnâmede; Şeyh Abdulkahhâr'ın, devlet güçleriyle aşiret reisleri arasında arabuluculuk yapmasından söz edilmiştir. Telgrafnâmede geçtiğine göre; Garzan'daki bazı aşiret reislerinin, "tenkil kuvvetleri" tarafından derdest edilmesi gerekmektedir. Ancak aşiretler buna mukavemet gösterebileceğinden, her iki tarafta da zayiat oluşacaktır. Zayiat oluşmaması maksadıyla sorunu çözmek için Şeyh Abdulkahhâr'ın aracılık yapmasından bahsedilmektedir. Buna göre Şeyh Abdulkahhâr, aşiret reislerinden devlete itaat etmek üzere yeminli söz alacak ve neticede affedilmeleri talep edilecektir. ${ }^{94}$ Burada Şeyh Abdulkahhâr, hem resmi yetkililer hem de aşiretler tarafından saygın bir sûfî olarak kabul gördüğünden dolayı sorunun çözülmesinde aracı olmuştur.

Şeyhlerin arabuluculuk rolü, kan davalarını önlemeye dönük de gerçekleşmiştir. Rivayet edildiğine göre; Şeyh Mahmud zamanında iki aile arasında cereyan eden bir kavgada, her iki aileden birer kişi ölür. Bu olayı duyan Şeyh Mahmud, hemen iki ailenin barışmasını sağlar. Bu barışın devam etmesi için de ölen iki kişiyi yan yana defnettirir. Böylece bu olayın kan davasına dönüşmesini engeller. ${ }^{95}$

\section{B. I. Dünya Savaşında Zokayd Tekkesi}

Tarihin en büyük savaşlarından biri olan I. Dünya savaşında, Osmanlı devleti topyekûn seferber olmuş ve birçok devlete karşı mücadele vermiştir. Bu savaşta şark vilayetleri Ruslara karşı savaşmıştır. Mücadelenin önemli bir katkısı da o dönemde topluma kanaat önderliği yapan şeyhlerle sağlanmıştır. Şeyhler, bulundukları bölgeyi işgale gelen düşmanlara karşı müritleriyle birlikte cihad etmişlerdir. Bu maksatla Norşin tekkesine bağlı olan Zokayd tekkesi de Şeyh Mahmud önderliğinde savaşa katılmıştır. Bitlis taraflarına giden Şeyh Mahmud'un beraberinde, mürid ve muhipleri olan bölgenin ileri gelen şahısları vardır. Bunlar arasında Garzan Babosi aşiretinin reisi Comanili İsmail-i Davud, Rıstak mıntıkasının reisi Osman Ağa ve Pencenari aşiretinin reisi Bişar-ê Çeto yer almaktadır. ${ }^{96}$ Şeyh Mahmud, bir ara savaş kızıştı-

\footnotetext{
94 BOA, DH.ŞFR., Dosya No: 271 Gömlek No: 4, Tarih: R-16-09-1316/29 Kasım 1900.

95 Sevgili, "Şeyh Mahmud ez-Zokaydî ve 'ed-Dâ' ve'd-Deva' Adlı Eseri”, 8.

96 Zokaydî, Menâkıbu'l-vâlidi'l-üstad eş-Şeyh Mahmud ez-Zokaydî ve'l-cedd eş-Şeyh Abdulkahhar, 41.
} 
ğında beraberindekilerle bir dağa tırmanmış, ancak dağın ortasında birden durmuştur. Neden durduğunu soranlara: "Sizden bu savaşta sonuna kadar mücadele etme sözü alacağım. Önce tüfeklerle savaşacă̆ız, mermimiz biterse taşlarla o da olmazsa dişlerimizle de olsa savaşıp geri kaçmayacağız." cevabını vermiştir. Beraberindekiler bu sözü tutacaklarını bildirirler. Bu şekilde düşmanın peşinden giderek dağın üzerine çıktıklarında, düşmanın savaşmadan erzak ve ganimeti terk edip kaçtıklarını görürler. Bunun Allah'ın bir lütfu olduğunu ifade eden Şeyh Mahmud, ateşte pişen yemekleri görünce zehirli olma ihtimaline binaen kimsenin dokunmamasını emreder. Bunun dişında orada bulunan şeker ve meyve gibi gıdaların yenilmesine müsaade eder.97

Bir ara savaşta yine çatışma sesleri duyulur. Şeyh Mahmud'la birlikte yemek yiyen müridlerinden Bişar-1 Çeto, çatışmaya girmek ister. Şeyh Mahmud "Yemeği bitirelim beraber gidelim." demesine rağmen o, hemen çatışmaya girer. Kısa bir süre sonra Bişar-1 Çeto'nun şehid düştüğü haberi gelir. Şeyh Mahmud onu elbiseleriyle birlikte defneder. ${ }^{98}$

\section{Milli Mücadelede Zokayd Tekkesi}

Milli mücadele döneminde, her kesimden olduğu gibi ulema ve meşayih sınıfından da mücadeleye katkıda bulunanlar vardı. Bu çerçevede Mustafa Kemal, şark vilayetlerindeki bazı şeyhleri Milli Mücadele sürecindeki gelişmelerden haberdar ediyor ve onların desteğini almaya çalışıyordu. Nitekim Nutuk'ta, şark vilayetindeki şeyhlere bu maksatla gönderdiği telgraflara rastlamaktayız. Bu telgraflardan biri, 13 Ağustos 1919'da Zokayd tekkesinin bağlı olduğu merkez Norşin tekkesinin başındaki Şeyh Muhammed Diyauddin'e çekilmiştir. Yine aynı tarihteki başka bir telgraf, "Şeyh Mahmud Efendi Hazretlerine" başlı̆̆ıyla gönderilmiştir. Her iki telgrafın aynı tarihte olması, ikinci telgrafın Şeyh Muhammed Diyauddin'in halifesi Şeyh Mahmud Zokaydî'ye gönderildiği ihtimalini ortaya koymaktadır. ${ }^{99}$ Yine aynı tarihli bir diğer telgrafın Şeyh Mahmud'la ilişkileri olan Garzan'daki Pencenari aşireti reisi Cemil-i Çeto (ö.1926) adına çekilmesi, bu

97 Zokaydî, Menâkıbu'l-vâlidi'l-üstad eş-Şeyh Mahmud ez-Zokaydî ve'l-cedd eş-Şeyh Abdulkahhar, 41-42.

98 Zokaydî, Menâkıbu'l-vâlidi'l-üstad eş-Şeyh Mahmud ez-Zokaydî ve'l-cedd eş-Şeyh Abdulkahhar, 42-43.

99 Bazı araştırmacılar, telgrafın Kuzey Irak'ta bulunan Şeyh Mahmud Berzencî́ye gönderildiğinden söz etmiştir. Ancak Berzencî́nin, telgrafın gönderildiği tarihten önce İngilizler tarafından tutuklanması, bu ihtimali zayıflatmaktadır (bkz. Serdar Sakin, "Osmanlı Mirası Üzerinde Etnik ve Siyasi Bir Hareket: Şeyh Mahmut Olayı", Perspectives on Ottoman studies: Papers from the 18th Symposium of the International Committee of Pre-Ottoman and Ottoman Studies (CIEPO) at the University of Zagreb 2008, ed. Ekrem Causevic, Nenad Moacanin, Vjeran Kursar, (Berlin: LIT Verlag Münster, 2010), II, 213). Serdar Sakin ise telgrafın Milli aşireti reisi Mahmud Ağa'ya gönderildiğinden bahsetmiştir (bkz. Sakin, “Osmanlı Mirası Üzerinde Etnik ve Siyasi Bir Hareket: Şeyh Mahmut Olayı", II, 213). Fakat bilindiği kadarıyla Mahmud Ağa bir aşiret reisi olup şeyh değildir. Dolayısıyla telgrafın Şeyh Mahmud Zokaydî'ye çekilmiş olması kuvvetle muhtemeldir. 
ihtimali güçlendirmektedir. ${ }^{100} 13$ Ağustos 1919 yılında Mustafa Kemal tarafından Şeyh Mahmud’a gönderilen telgraftaki bazı ifadeler şöyledir:

“...Sizin gibi özverili yurtsever din kardeşlerimin benimle birlikte çal1şacağına inanıyorum. Bu kere Erzurum Kongresince kararlaştırılan bildiri ve tüzüklerden sunuyorum. $O$ yöreden örgütlerin yayılması ve güçlendirilmesi için yoğun çaba harcamanızı rica ederim. Yakında Sivas'ta toplanacak olan genel bir kongre ile de daha yararlı ve kesin sonuçlar elde edileceği kuşkusuzdur. O yörede İngilizlerin aldatıcı telkinlerinin önüne geçilmesi çok gereklidir. Cenabı Hak cümlemize muvaffakiyetler buyursun. Gözlerinizden öperim Efendim." ${ }^{101}$

Zokayd tekkesinin milli mücadelede takındığı tavır, işgal kuvvetlerine karşı yapılan protestolara katılmakla belirginleşmektedir. $\mathrm{O}$ dönemde işgal edilen şehirler, ülkenin dört tarafında tertiplenen mitinglerle protesto ediliyordu. Bu kapsamda 15 Mayıs 1919' daki İzmir işgali de Siirt halkınca protesto edilmiştir. Nitekim Siirt halkı işgali duyduğunda, 19 Mayıs 1919' da Siirt merkezde Camii Kebir'in önünde, kadın ve erkeklerden oluşan kırk bin kişilik kalabalık bir miting düzenleyip işgali protesto etmiştir. ${ }^{102} \mathrm{Bu}$ protestonun bir parçası olarak; aralarında Şeyh Mahmud Zokaydî́nin de bulunduğu Garzan'ın ileri gelenleri, hariciye nezaretine bir telgraf gönderirler. Telgrafta bu işgale karşı mücadele etmeye hazır oldukları şöyle ifade edilmiştir: " $\mathrm{Ha}$ rekât-ı zalimanelerine bütün mal ve canımız ve mevcudiyetimizle müdafaaya her zaman amade bulunduğumuzu arz u beyan eyleriz". 103

Yine Fransız işgal kuvvetlerinin zulümlerini protesto için General Gouraud'a iletilmek üzere, Sadâret'e 4 Mart 1920 Garzan çıkışlı bir telgraf çekilmiştir. Telgrafta, Maraş’ın Fransızlar tarafından işgal edilmesi protesto edilmiştir. Telgrafın altında başta Garzan Müdafaa-i Hukuk Cemiyeti Reisi Faik' in yanı sıra birçok ulema, meşayih ve eşrafın ismi yer almaktadır. Şeyhlerden, Norşin şeyhleri Şeyh Muhammed Diyauddin ile Şeyh Masum ve Şeyh Mahmud Zokaydî’nin ismi bulunmaktadır. Telgrafın içeriğindeki bazı ifadeler şöyledir:

“...Maraş ve çevresindeki Fransız işgal kuvveti ve bu ad altında önceden beri Rusya ve diğer yerlerden derme çatma toplanan Ermeni çeteleri, namusu, dini, hayatı, masumiyeti, özetle insanlık duygularını uzaklaştıran, parçalayan, ayaklar altında sürükleyen haydutluklarını ve mel'unca hareketlerini hiçbir aklın alamayıp, hiçbir vicdanın kabul edemeyeceği bir şekle sokmuşlardır..."

\footnotetext{
100 Üç telgraf, Nutuk'ta art arda yer almaktadır. bkz. Mustafa Kemal Atatürk, Nutuk (Söylev): Orijinal ve Günümüz Türkçesi ile, haz. Hasan Yıldız, (İstanbul: Hukuk Kitapevi, 2018), 917-921.

101 Atatürk, Nutuk, 917.

102 Ömer Obuz, "Milli Mücadeleye “Şark”tan Bir Destek: Siirt Örneği”, Pamukkale Üniversitesi Sosyal Bilimler Enstitüsü Dergisi, 27 (Mayıs 2017): 269-270.

103 Obuz, "Milli Mücadeleye "Şark" tan Bir Destek: Siirt Örneği”, 270 (BOA, HR. SYS, 2552/7).
} 
“...Maraş yanıyor. Alevlerin arasından yükselen kadınlarımız ve genç kızlarımızın içimizi parçalayan feryatları, mukaddes makamlarımızda yankılanıyor. İmdat isteyen bu feryatlar Garzan muhitindeki bütün aşiretleri ayağa kaldırmış ve kendiliğinden bir miting yapılmasına sebep olmuştur..."104

\section{Sonuç}

Zokayd tekkesini, meşhur müderris Molla Halil es-Si'irdî'nin torunu Şeyh Abdulkahhâr tesis etmiştir. Şeyh Abdulkahhâr müderris olduğundan tekkenin yanında bir de medrese kurmuştur. Dolayısıyla buradaki şeyhler aynı zamanda birer müderristiler. Hatta tekkenin tarihini bütün olarak değerlendirdiğimizde, medresenin daha aktif olduğunu görmekteyiz. Bunun arka planında ailenin medrese kökenli olması yer almaktadır. Bu özelliğinin yanı sıra, tekkede irşad faaliyetleri de etkin bir biçimde sürdürülmüştür.

Genel olarak Zokayd tekkesinin özellikleri şöyle sıralanabilir;

1. Tekkedeki şeyhler -Şeyh Haydar'ın Molla Abdussamed'e hilafet verdiği iddiasını bir kenara bırakırsak- kendi çocukları dâhil kimseye hilafet vermemişlerdir. Ancak medresede tasavvufî meşrebe sahip birçok âlim yetiştirmişlerdir.

2. Tekkenin postnişînleri, mürşid olan babaları ve ağabeylerinden tasavvufî bir eğitim almalarına rağmen, başta merkez tekke Norşin olmak üzere diğer Hâlidî tekkelerine gidip hilafet almışlardır. Bu da tekkedeki şeyhlerin, irşad vazifesini ciddiye aldıklarını ve postnişînliğin babadan oğula kolayca intikali yerine, başka tekkelerden desteklenen tasavvufî eğitimle elde edilmesini önemsediklerini göstermektedir.

3. Zokayd şeyhleri, tarih ilmine ve edebiyata önem vermiş, seyahate gittiklerinde ya da sürgün edildiklerinde hatırat türü eserler yazmışlardır.

4. Zokayd şeyhleri, hatla meşgul olmuşlar ve başta dedeleri Molla Halil es-Si'irdî'nin olmak üzere birçok eseri istinsah edip bunların sonraki nesillere ulaşmasına katkıda bulunmuşlardır.

5. Zokayd şeyhleri, tecvide dair eserler yazmışlardır. Dolayısıyla bölgede tecvid ilmiyle iştigal eden nadir merkezlerden olmuştur.

104 Osmanl Belgelerinde Ermeni-Fransız İlişkileri (1920-1922), (Ankara: T.C. Başbakanlık Arşivleri Genel Müdürlüğü Osmanlı Arşivi Daire Başkanlığı, Yayın no: 66, 2003), III, 193-194 (BOA. HR. SYS. 2544-14/11-12). 
6. Zokayd medresesinde bölgedeki diğer medreselerden farklı olarak Farsça tasavvufî eserler okutulmuştur.

7. Zokayd şeyhleri, bölgedeki gayrimüslimlerle sağlıklı bir iletişim kurup onların Müslüman olmalarına vesile olmuşlardır.

8. I. Dünya savaşında tekkenin o dönem postnişîni Şeyh Mahmud, müridleriyle birlikte savaşa bizzat katılmış ve düşmanla mücadele etmiştir.

9. Milli Mücadele döneminde düşman askerlerinin protesto edilmesinde Zokayd tekkesi tavrını ortaya koymuş ve kendi bölgesinde yapılan protestolara iştirak etmiştir.

\section{Kaynakça}

\section{Arşiv Belgeleri ve Salnâmeler}

BOA, A.MKT.MHM., Dosya No: 501 Gömlek No: 30, Tarih: H 2203 1308/5 Kasım 1890.

BOA, DH.ŞFR., 271/4, Tarih: R-16-09-1316/29 Kasım 1900.

Osmanlı Belgelerinde Ermeni-Fransız İlişkileri (1920-1922). Ankara: T.C. Başbakanlık Arşivleri Genel Müdürlüğü Osmanlı Arşivi Daire Başkanlığı, Yayın no: 66, 2003, I-III.

Salnâme-i Nezaret-i Maarif-i Umumiyye. İstanbul: Matbaa-i Amire, 1318/1900.

Salnâme-i Vilâyet-i Bitlis. Bitlis: Bitlis Vilayet Matbaası, 1310/1892.

\section{Kaynak ve Araştırma Eserler}

Adak, Abdurrahman. "Şeyh Cüneyd-i Zokaydî ve Mahtut Bir Şiir Mecmuası". Şarkiyat İlmi Araştırmalar Dergisi, 1/1 (Nisan 2009): 133-139.

Atatürk, Mustafa Kemal. Nutuk (Söylev): Orijinal ve Günümüz Türkçesi ile. haz. Hasan Yıldız, İstanbul: Hukuk Kitapevi, 2018.

el-Bâbânî el-Bağdâdî, İsmail Paşa. Hediyyetu'l-'ârifinn. Beyrut: Dâru ihyâi't-turâsi'l'Arabî, 1951, I-II.

Baz, İbrahim. Şeyh Asım Ohinî ve Birketü'l-kelimât fî menâkıb-ı ba'di's-sâdât İsimli Eseri. İstanbul: Nizamiye Akademi, 2018.

.Şeyh Muhammed Hazîn Firsâfí: Hayatı Eserleri ve Görüşleri. Ankara: İlahiyat Yayınları, 2016. 
Câmî, Abdurrahman. Nefehâtü'l-üns min hazarâti'l-kuds. tsh. ve ta'lik Mahmud Âbidî, Tahran: İntişârât-1 İttilâ'ât, 1370 hş.

Demircan, Nezir. Halil Günenç Hoca: Hayatı ve Hatıratı. İstanbul: Beyan Yayınları, 2004.

Ildırar, Mehmed ve Çağıl, Ahmed. Seyyid Abdülhakim El-Hüseynî (Gavs-ı Bilvanisî Hayatı). Ankara: Menzil Kitabevi, 1996.

Kavak, Abdulcebbar. Mevlânâ Hâlid-i Nakşibendî ve Hâlidîlik. İstanbul: Nizamiye Akademi, 2016.

Korkusuz, Şefik. Nehrî'den Hazne'ye Meşayih-i Nakşibendî. İstanbul: Pak Ajans Yayınc1lik Ltd. Şti., 2010.

Memduhoğlu, Adnan. "Mahmud Zokaydî”. Türkiye Diyanet Vakfi İslam Ansiklopedisi, İstanbul: Türkiye Diyanet Vakfı, 2016, EK-2, 180-181.

Norşinî, Muhamd Diyauddin (Ahmed Haznevî ile birlikte). Mektûbât. Çev. Hasib Seven, İstanbul: Yaylacık Matbaası, 1977.

Nursî, Abdurrahman. Bediüzzaman'ın Hayatı. yay. Osman Resulan, İstanbul: Nubihar Yayınları, 1997.

26 Obuz, Ömer. “Milli Mücadeleye “Şark”tan Bir Destek: Siirt Örneği”. Pamukkale Üniversitesi Sosyal Bilimler Enstitüsü Dergisi, 27 (Mayıs 2017): 264-276.

Ohinî, Âsım. Birketü'l-kelimât. y.y., trsz.

Pakiş, Ömer. "Molla Halîl es-Siirdî”. Türkiye Diyanet Vakfi İslam Ansiklopedisi, İstanbul: Türkiye Diyanet Vakf1, 2005, XXX, 250-251.

Sakin, Serdar. “Osmanlı Mirası Üzerinde Etnik ve Siyasi Bir Hareket: Şeyh Mahmut Olay1". Perspectives on Ottoman studies: papers from the 18th Symposium of the International Committee of Pre-Ottoman and Ottoman Studies (CIEPO) at the University of Zagreb 2008, ed. Ekrem Causevic, Nenad Moacanin, Vjeran Kursar, 207222. Berlin: LIT Verlag Münster, 2010.

Sevgili, Abid. "Şeyh Mahmud ez-Zokaydî ve 'ed-Dâ' ve'd-Deva' Adlı Eseri”. Yayımlanmamış Yüksek Lisans Tezi, Dicle Üniversitesi Sosyal Bilimler Enstitüsü, Diyarbakır 2011.

Sevgili, Hamit. "Şeyh Mahmûd Zokaydî'nin 'Kitâbu Âdâbi'l-Hukûki ve Hüsni'sSuhbe' Adlı Eseri Bağlamında Âdâb-1 Muâşeret ile İlgili Görüşleri”. Siirt Üniversitesi Sosyal Bilimler Enstitüsü Dergisi, 5/10 (2017): 599-621.

Sevgili, Mehmet Macit. “Zokayd Medrese ve Tekkesinin Veysel Karenî Yöresindeki Etkileri". Uluslararası Veysel Karenî ve Mânevî Kültür Mîrâsımız Sempozyumu, 20-21 Mayıs 2011 Siirt, ed. Mehmet Bilen ve Şevki Efe, Matser Basım Yayım, (Ankara: 2012), 193-213. 
Şarânî, Abdulvehhab. et-Tabakâtü'l-kubrâ: Levâkıhu'l-envâri'l-kudsiyye fî menâkibi'lulemâ ve's-sûfiyye. thk. Ahmed Abdurrahim es-Sâyih-Tevfîk Ali Vehbe, Kahire: Mektebetü's-Sakafetü'd-Diniyye, 2005, I-II.

Şîrâzî, Hâfız. Dîvân-ı Hâfız. Tahran: İntişârât-ı Kitâb âbân, 2010.

Tâhî [Tâğ̂̂], Abdurrahman. Mektûbât-ı Seyda-i Tâhî. Çev. Ahmet Şahin, İstanbul: Semerkand Yayınları, 2013.

Taşğın, Ahmet. "Yezîdiyye". Türkiye Diyanet Vakfi İslam Ansiklopedisi, İstanbul: Türkiye Diyanet Vakf1, 2013, XXXXIII, 525-527.

Vefâî, Mirza Abdurrahim Savicbulağî. Tuhfetü'l-mürîdîn. y.y., tsz.

Zokaydî, Abdulkahhâr. Tercemetü el-Allâme el-Fehhâme el-Molla Halil. y.y., tsz.

Zokaydî, Fudayl. Menâkıbu'l-vâlidi'l-üstad eş-Şeyh Mahmud ez-Zokaydî ve'l-cedd eş-Şeyh Abdulkahhâr. y.y., 1400/1980.

Zokaydî, Mahmud. et-Teb'îd ilâ Antalya ve's-seyâha fî diyâri'l-İslâm. y.y., tsz. ed-Dâve'd-devâ. y.y., tsz. 
Ekler

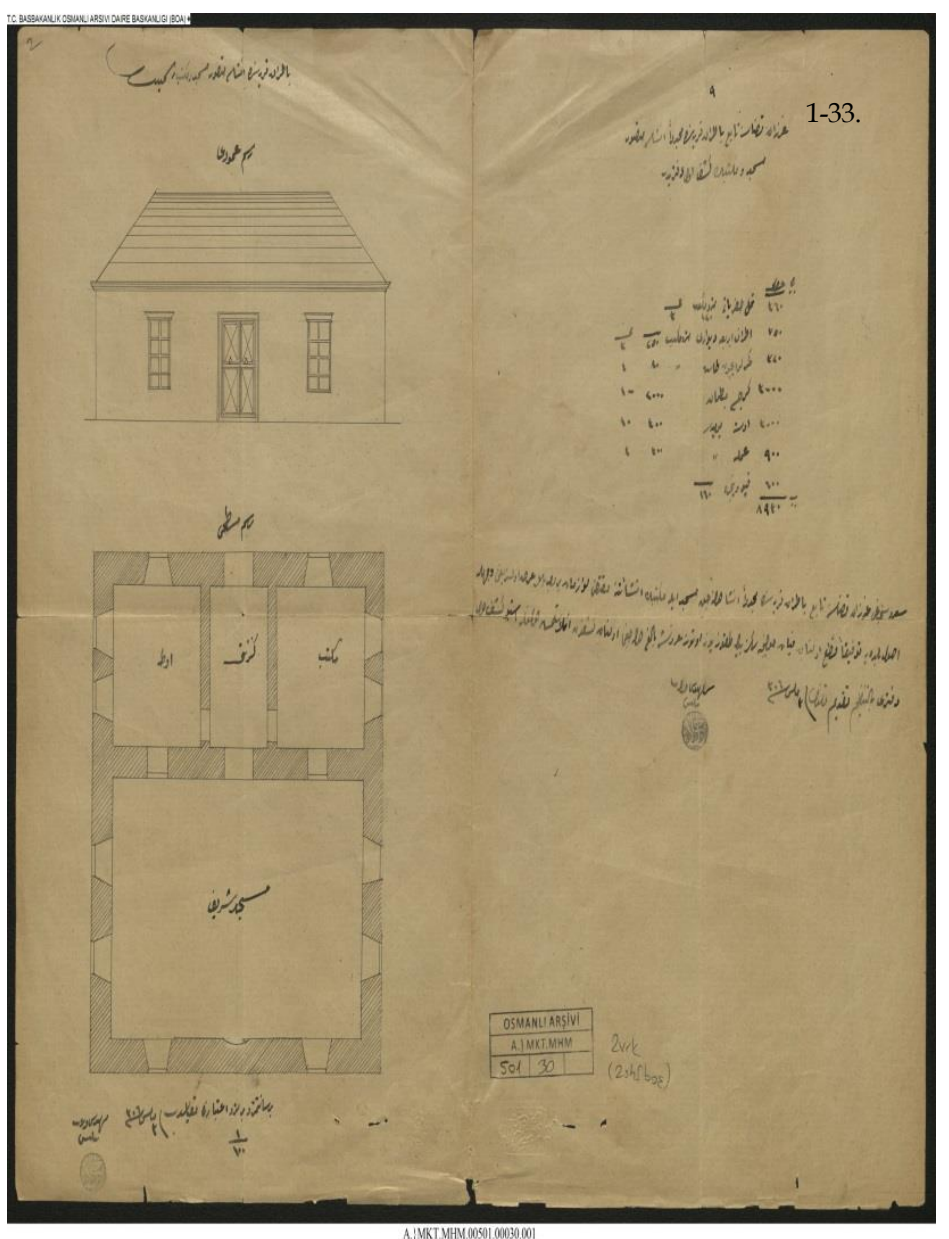

Sultan Abdülhamid'in halkı Müslümanlaşan Yezîdî köyüne yaptırdı̆̆ı mescid ve mektebin planı 


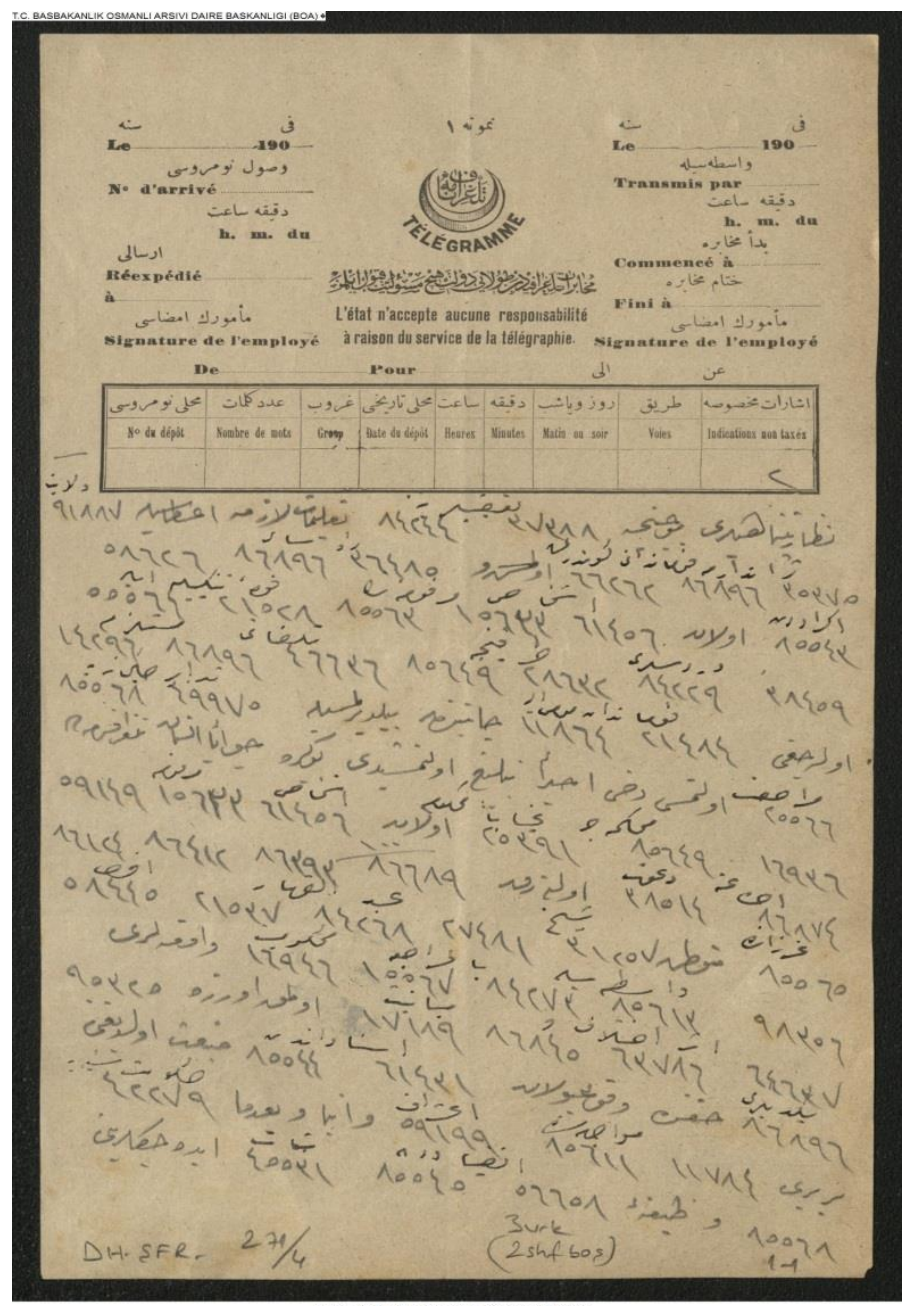

DH.ŞFR.00271.00004.001

Şeyh Abdulkahhâr'ın arabuluculuk yapmasından bahseden şifreli arşiv belgesinin ilk sayfası 


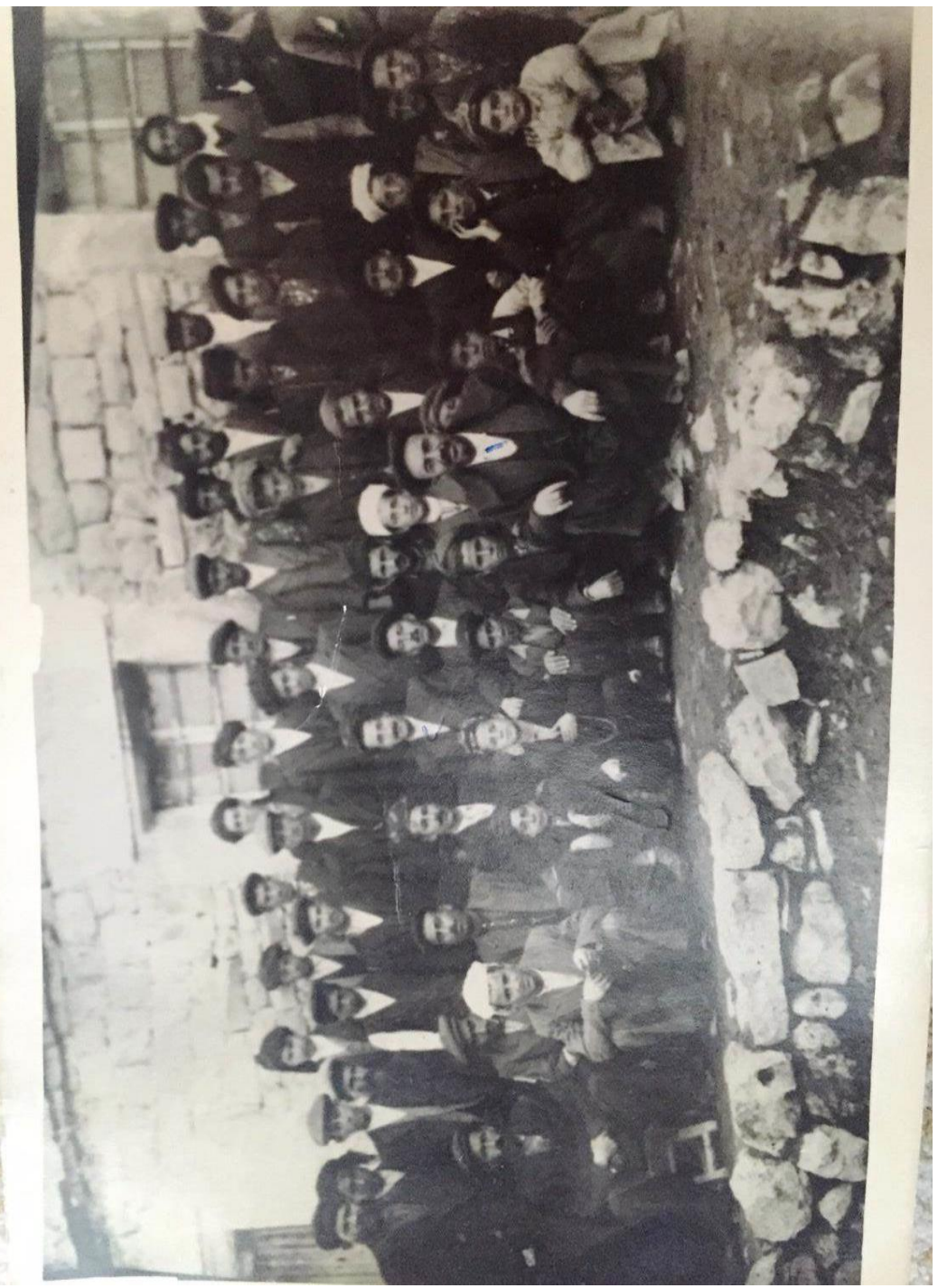

Zokayd Medresesi talebeleri (Macit Sevgili'den alınmıştır) 


\section{Zokayd tekkesi postnişînlerinin tarikat silsilesi (oval şemalar Zokayd şeyhleridir)}

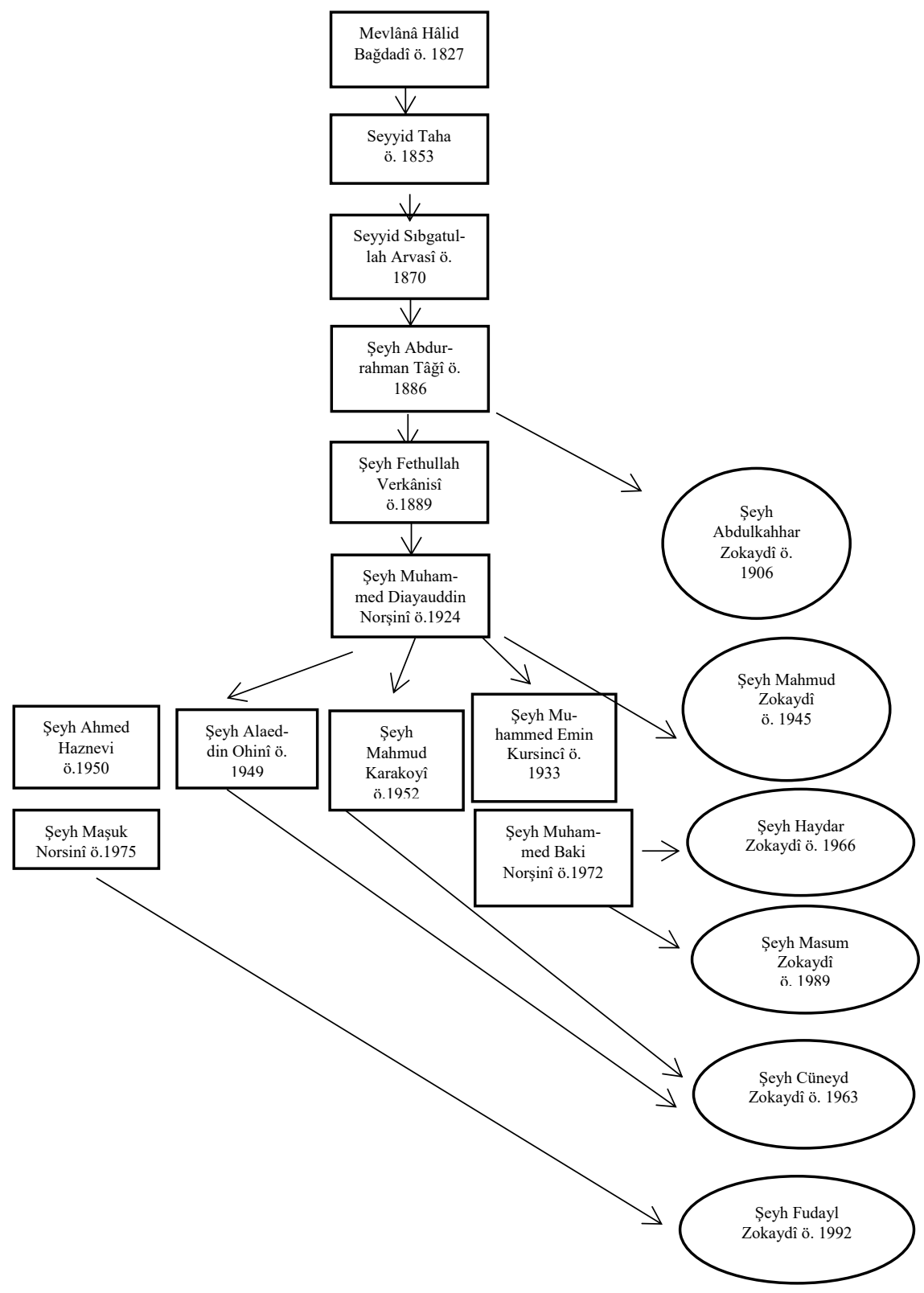


Doi: 10.34247/artukluakademi.553711

Mehmet Saki Çakır

\section{A Naqshī-Khālidī Sufi Centre in Siirt: The Takka and Madrasa of Zoqayd}

Citation/@: Çakır, Mehmet Saki, A Naqshī-Khālidī Sufi Centre in Siirt: The Takka and Madrasa of Zoqayd, Artuklu Akademi 2019/6 (1), 1-33.

\section{Extended Abstract}

The Sufi orders change and leave their mark on the society in which they coexist. To evaluate the religious, social and cultural patterns of the people in the region in which these orders are effective, the doctrine of the sufi order must be taken into account. One of these centers, which have been active until recent years, is the sufi order (takka) named Naqshi-Khālidī Zoqayd in Siirt. The Zoqayd takka was founded in the late 19th century in the village of Zoqayd in Garzan a district of Siirt (today, Kayabağlar borough of Kurtalan). The order adopted the doctrines of Naqshī-Khālidī sufism. Sheikh Abd al-Qahhār Zoqaydī established this takka. In his time, Sheikh Zoqaydī played a major role in spreading the Sufism in the Siirt province. The spiritual chain (silsila) from Sheikh Abd al-Qahhār to Mawlāna Khālid Baghdādī is as follows: Sheikh Abd al-Qahhār Zoqaydī- Sheikh Abd al-raḥmān Tāghī- Sayyid Șibghatullah ArwasīSayyid Taḥā Ḥakkārī- Mawlāna Khālid Baghdādī.

Sheikh Abd al-Qahhār was the son of Mulla Mahmūd, who was the son of Mulla Khalīl al-Siirdī. Mulla Khalīl engrafted the classical madrasa education system and after him this system has been transmitted from one generation to the next one. Therefore, in the history of the Zoqayd madrasa and in the other madrasas in the region, we can observe the impact of Mulla Khalì and his children.

Mulla Abd al-Qahhār, who was remained distant to Sufism, decided to turn to Sufism upon a dialogue with Sheikh Khālid Orakī. Mulla Abd al-Qahhār received his first spiritual training from Sheikh Muhammad Ḥazīn Firsāfĩ. He later departed from him and completed his spiritual training under the supervision of Sheikh Abd al-raḥmān Tāghī in Norshin. With the suggestion of his sheikh, Sheikh Abd al-Qahhār settled in Halenze (Bağtepe) village of Siirt. He, later, moved to the Botan a district in the east part of Siirt and started to give spiritual guidance (irshād). He finally settled in Zoqayd village of Garzan upon the prescription of Sheikh Abd al-rahmmān. He built a lodge and madrasa there. The beginning of the period of Sheikh Zoqaydì in Zoqayd corresponds to the 1880s. In general, it can be said that the spiritual guidance of the Zoqayd takka has been effective in the large part of Siirt province. Although Sheikh Abd alQahhār did not leave a caliph behind him, he had a profound impact on many important figures living in this region. Some of them were Sayyid Abd al-hakīm Bilwanisī, who established the Manzil sufi order in Adiyaman, and Said Nursī. Sheikh Abd al-Qahhār died in 1324/1906. His tomb in Zoqayd is still visited by people.

After Sheikh Abd al-Qahhār, his son Sheikh Mahmūd took over the Zoqayd takka. Sheikh Mahmūd, who first received sufi education from his father, sought for sheikh after his father's death. Finally, he decided to become a fol- 
lower of Sheikh Muhammad Diya al-dinn Norshin (d.1924), the son of Sheikh Abd al-raḥmān Tāghī. Sheikh Maḥmūd, who completed his spiritual training (sayr al-sulūk) in a short time, became a caliph and returned back to Zoqayd. He both trained his followers and gave lectures in the madrasa. In addition, he wrote more than twenty works in different fields. His works are on ușul al-fiqh, hadith, history, literature and tajweed. Sheikh Mạmmūd died in 1364/1945 and buried in the same cemetery like his father.

Sheikh Mahmūd had seven sons. All of them received education in the Zoqayd madrasa and later, they taught in the same madrasa. Their names are Ahmad, Ḥaydar, Ma'sūm, Junayd, Salaḥaddīn, Fựayl and Yahyā. After Sheikh Mạmmūd, his sons Sheikh Ḥaydar, Sheikh Junayd and Sheikh Fuḍayl were visibly involved in the sufi order's and madrasa's activities. Until the 1990s, Zoqayd takka and madrasa continued to be functional. Today, Mulla Șibghatullah Sevgili, son of Sheikh Fuḍayl, carries out the madrasa activities.

Considering the general characteristics of the Zoqayd sheikhs, it was seen that they did not delivered halifelik/a special permission (a subsequent consent to guide people in their spiritual journey) to anyone, including their children. In Zoqayd takka the spiritual chain does not typically pass from father to son. Scholars, who were trained in Sufism and were raised in the Zoqayd madrasa, moved to other Khālidī sufi orders, such as Norhsin and received this special permission there. The sheiks in this order attached also importance to history and wrote travel accounts during their journeys or when they were expelled. Another common feature of these sheikhs in this order is that they studied tajweed (a set of rules for proper pronunciation and recital of the Qur'an), which is rarely studied in the region. The sheikhs of Zoqayd established healthy communication with the Yazīdi community in the region and guided them, when they wanted to convert to Islam.

In the Zoqayd madrasa, unlike other madrasas in the region, Persian sufi texts were read and taught. In the World War I, Sheikh Mahmūd, the sheikh of that period in the order, personally joined the battle with his murids (followers) and fought against the allied powers. During the war of independence (Milli Mücadele) in Turkey, Zoqayd takka participated in protests against allied powers. 